\title{
DECLINE OF ANTIQUITY AND THE BEGINNING OF A NEW ERA IN THE POLISH CARPATHIANS ${ }^{1}$
}

\author{
Renata Madyda-Legutko - Krzysztof Tunia
}

DOI: https://doi.org/10.31577/szausav.2020.67.14

Keywords: Carpathians, Late Roman Period, Migration Period, North Carpathian Group, Early Slavs

\begin{abstract}
The paper presents the cultural situation on the northern slopes of the West Carpathians during the Late Roman, the Early Migration and the beginning of the Early Medieval periods. At the close of antiquity, the western part of the area under discussion was inhabited by communities referred to as the North Carpathian group. Their settlement model in that period included single-household settlements situated in high locations, and big settlements in wide river valleys on the edges of overflowing terraces. People living in these settlements maintained contact with the northern, mountainous part of Slovakia, and also with the Carpathian Basin, the Danube River basin, and the post-Chernyakhov culture milieu. A new cultural cycle was initiated in the West Carpathians by the inflow of early Slavic groups representing the so-called Prague cultural province into the southern Vistula River basin. The decline of settlement of the North Carpathian group and the appearance of that linked with early Slavs both seem to fall around the middle of the $5^{\text {th }}$ century, and there may have been a causal link between these two phenomena.
\end{abstract}

The development of archaeological cultures belongs among the most difficult questions in prehistoric studies. Periods of their more or less stable development are typically relatively well-defined, but issues related with their appearance and disappearance pose many more problems and often raise controversy. This also holds true with respect to the close of antiquity and the beginning of the Middle Ages in the West Carpathians, a territory we have already paid much attention to, and which is the focus of this paper as well.

Thanks to field research carried out over recent years, the Beskid part of the Polish Carpathians has ceased to be a terra incognita on the archaeological map of Central European Barbaricum in the Late Roman and early Migration periods. Quite to the contrary, the region has turned out to have been intensively exploited in that period.

The Late Roman period saw expansion of settlement into the Beskid zone, into areas sparsely settled or uninhabited in previous periods - Beskid Zachodni, from where Púchov culture sites are known, and Beskid Wschodni on the San River, where Przeworsk culture sites from the Early Roman period were recorded.

A leading role in the settling of the Carpathians is ascribed in older Polish archaeological literature to Przeworsk culture populations expanding southwards from central Małopolska. This expansion is believed to have been caused by demographic growth and by adaptations in the economic model which allowed for exploitation of mountainous environments (Madyda-Legutko/Poleski/Krapiec 2005, 310, 311, fig. 1; Madyda-Legutko/Tunia 2008, 245, 246). According to another view, the part of the Carpathians within the range of the so-called North Carpathian group was settled in the Late Roman period by a new population of unspecified origin (Pieta 1991, 376).

The natural environment of the Carpathian areas allowed for farming-herding economy, as has been demonstrated by results of paleobotanical and archaeozoological research. Settlement sites yielded remains of barley (Horodeum vulgare L.), rye (Secale cereale L.), common wheat (Triticum aestivum L.), emmer wheat (Triticum dicoccum L.), spelt (Triticum spelta L.), millet (Panicum miliaceum L.) and oat (Avena sp.; Lityńska-Zajac 1993, 155; Lityńska-Zając et al. 2017, 719-750), as well as bones of domesticated animals.

1 The text was presented at the conference: 31. Internationales Symposion. Grundprobleme der frühgeschichtlichen Entwicklung im mittleren Donauraum. Das Ende und der Anfang. Abschlußphase der römischen Kaiserzeit im Mitteldonauraum, held in Nitra on 19.-22. November 2019. The study was realised within the VEGA projects no. 1/0358/18 'Roman fort at Iža and its position on the border of Pannonia'. 


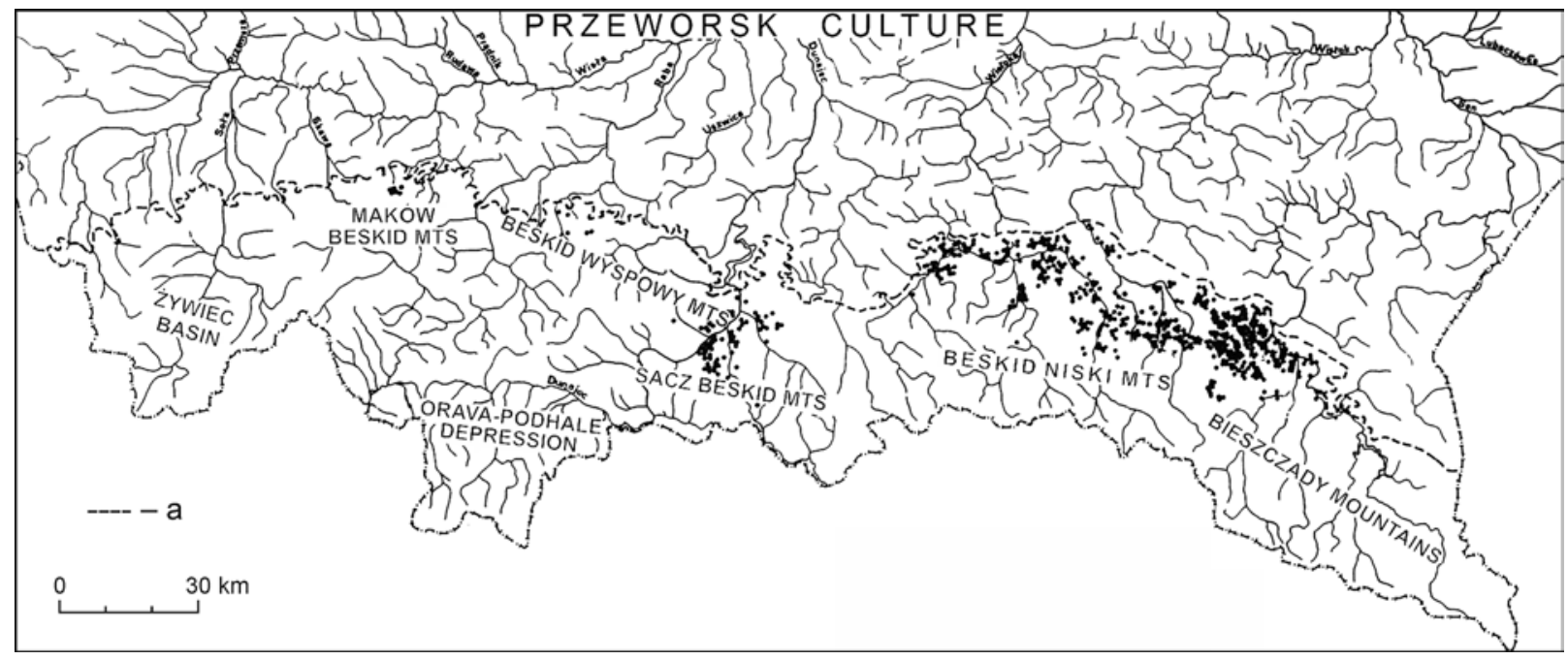

Fig. 1. Late Roman and Early Migration periods settlement in the Polish Beskid Mts. Legend: a - north border of the Beskid zone (elaborated by R. Madyda-Legutko).

Unfortunately, the high acidity of Carpathian soils causes that bone materials hardly ever survive in settlement sites (Madyda-Legutko/Tunia 1978, 146; Tunia 2004, 347). In the few cases where bones have survived, the identified species included cattle (Bos taurus) and domestic pig (Sus domesticus). ${ }^{2}$ It cannot be ruled out that the region may have also attracted settlers with its salt springs, which have been documented in the Carpathians (e. g. Góry Słone, Tyrawa Solna, Słonka River; Bochnak 2019, 25-56, fig. 3; Cabalska 1971, 431-436; Jodłowski 1985, 59-69). It is also worth noting that the gentle landscape of the Beskid zone, with a number of low passes and longitudinal river valleys, does not make this part of the Carpathians any significant morphological barrier to communication between the valleys of the Danube and Vistula Rivers, to local contacts among inter-mountain valleys, or to communication between northern and southern foothills of the Carpathians.

The current picture of Late Roman and Early Migration periods settlement in the area under discussion (both in Poland and Slovakia) is naturally a reflection of the current state of research, and advances in research could bring some corrections to that picture in future. The relatively well-understood settlement in the mountain valleys of the Orava, the Spiš, the Liptov, the Sącz Basin, and in adjacent mountain ranges, was described by Karol Pieta as the North Carpathian group. According to that scholar, the group in question occupied an area extending between the Malá Fatra range to the west and the Torysa River to the east, with the northern and southern boundaries marked by the northern margins of the Sącz Basin and the Low Tatras, respectively (Luštíková 2018, 80, pl. VI; Pieta 1987; 1991; 2003, 156-158, fig. $5 ; 6 ; 2008,464-467$, fig. 5: 1-21). K. Pieta argued that the populations recorded in the area in the Late Roman and Early Migration periods settled a territory which had previously been almost completely uninhabited (Pieta 1994, 254). The picture of settlement is different in eastern Slovakia. Although the region remains poorly recognised, the Late Roman and Early Migration periods occupation (Tunia 2001, 113 , fig. 3; 2008, 132, 133) was demonstrated to have been pre-dated there by settlement from phase C2 of the Younger Roman period (Lamiová-Schmiedlová/Tomášová 1999; Prohászka 2006).

In light of the current state of research in the Beskid zone of Polish Carpathians, the occupation from the period of our interest is clearly evident in the Sącz Basin and the surrounding mountain ranges (Beskid Sądecki and Beskid Wyspowy), in the Jasło-Krosno Basin together with Beskid Niski, and in the upper basin of the San River - from the Sanok Basin to the Bieszczady Mts (Fig. 1; 23; Ginalski/Muzy-

2 Rytro, Nowy Sącz distr. - bone fragment (Sus sp.?; Madyda-Legutko/Tunia 1993, 24); Ujazd, Jasło distr. - cattle bones (Bos taurus; Pęcherek 2018); Pakoszówka, Sanok distr., site 1 - a cattle bone (Bos taurus; Madyda-Legutko/Pohorska-Kleja/Rodzińska-Nowak, in preparation); Sanok, Sanok distr., site 54 - bones of cattle and pig (Sus domesticus, Bos taurus; Madyda-Legutko et al., in preparation); Lesko, Lesko distr. - a few animal bones (Barłowska 1984, 56, 70, 72).

3 The maps presented here show both excavated sites and those identified by surface surveys only. The chronology of the latter was determined based on wheel-made pottery found on the surface, which allows for only a broad dating to a period spanning from the Late Roman period to the early phase of the Migration period. 


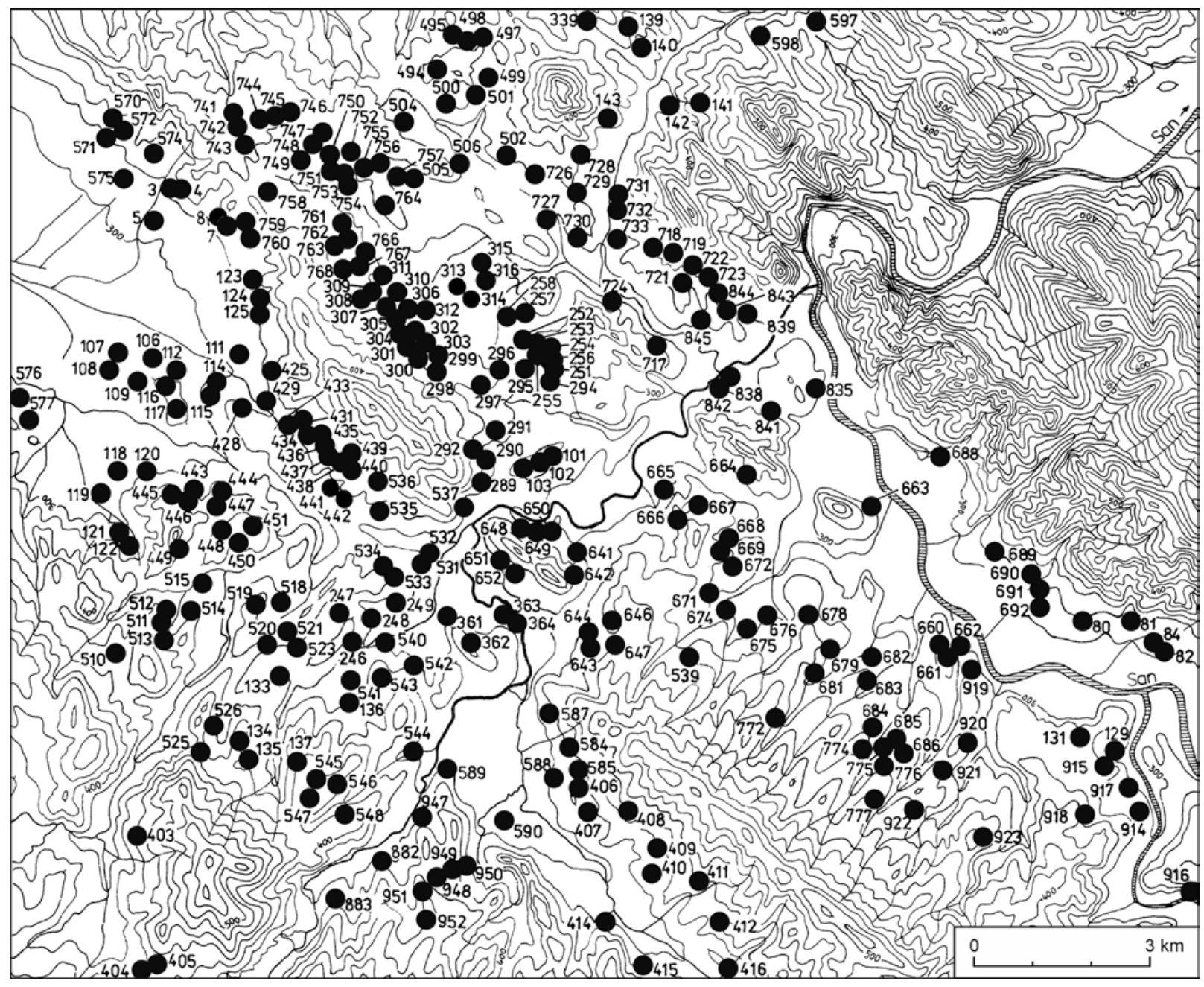

Fig. 2. Late Roman and Early Migration periods settlement in the eastern part of the Jasło-Krosno Basin together with the Beskid Niski Mts and the upper San River basin (Madyda-Legutko 1995, map 4).

czuk 2001, 193, pl. III: c-e; Madyda-Legutko 1995, list III; map 4; 1996, 67-70; Madyda-Legutko/Tunia 2008, 227-248; Parczewski/Pelisiak/Szczepanek 2012, 25-27).

In the Sącz Basin and adjacent areas, the occupation from the period under discussion was pre-dated by that of the Púchov culture, dated from the La Tène period to the Early Roman period (Madyda-Legutko 1996, 47-51; Madyda-Legutko/Tunia 2015). In addition, finds of Roman coins dated to the reigns of Augustus and Tiberius (14-37 AD) are known from the Jasło-Krosno Basin (Dymowski 2013, 275-278, fig. 1; 2). Small amounts of pottery broadly dated to the Early Roman period have also been identified among surface materials in the Sącz Basin, Beskid Sądecki, and Beskid Wyspowy. ${ }^{4}$ Settlement datable to the Early and Younger Roman periods, linked with the Przeworsk culture, is confirmed in the upper San River Basin as well (Bulas/Kotowicz/Okońska 2019, 91-106; Madyda-Legutko/Rodzińska-Nowak 2010, 65-77; 2019, 247-258). Later, $3^{\text {rd }}$ century occupation of that area is evidenced by single finds, one example being an aureus coin of Emperor Tacitus (275-276) from Gostwica, Nowy Sącz district (Fig. 3: 2), perforated and provided with a loop for suspension, which belongs to specimens having other than economic function (Morawiecki 1977, 175, 176, fig. 2a, b). A glass sword pommel recently discovered in Łukowica, Limanowa district, site 5, is a very interesting specimen (Fig. 3:1), ${ }^{5}$ which testifies to contacts with the Sarmatian milieu, and perhaps with northern Europe as well (cf. Biborski/Kaczanowski 2013, 423, 424, fig. 2; 3; 4). Imported terra sigillata vessels also reached the Beskid zone. In the Dynów Foothills, in Bachórz, Rzeszów district,

4 Unpublished materials from Krzysztof Tunia's research.

5 Unpublished find, collection of the Regional Museum in Nowy Sącz; Bartłomiej Urbański (in preparation). 


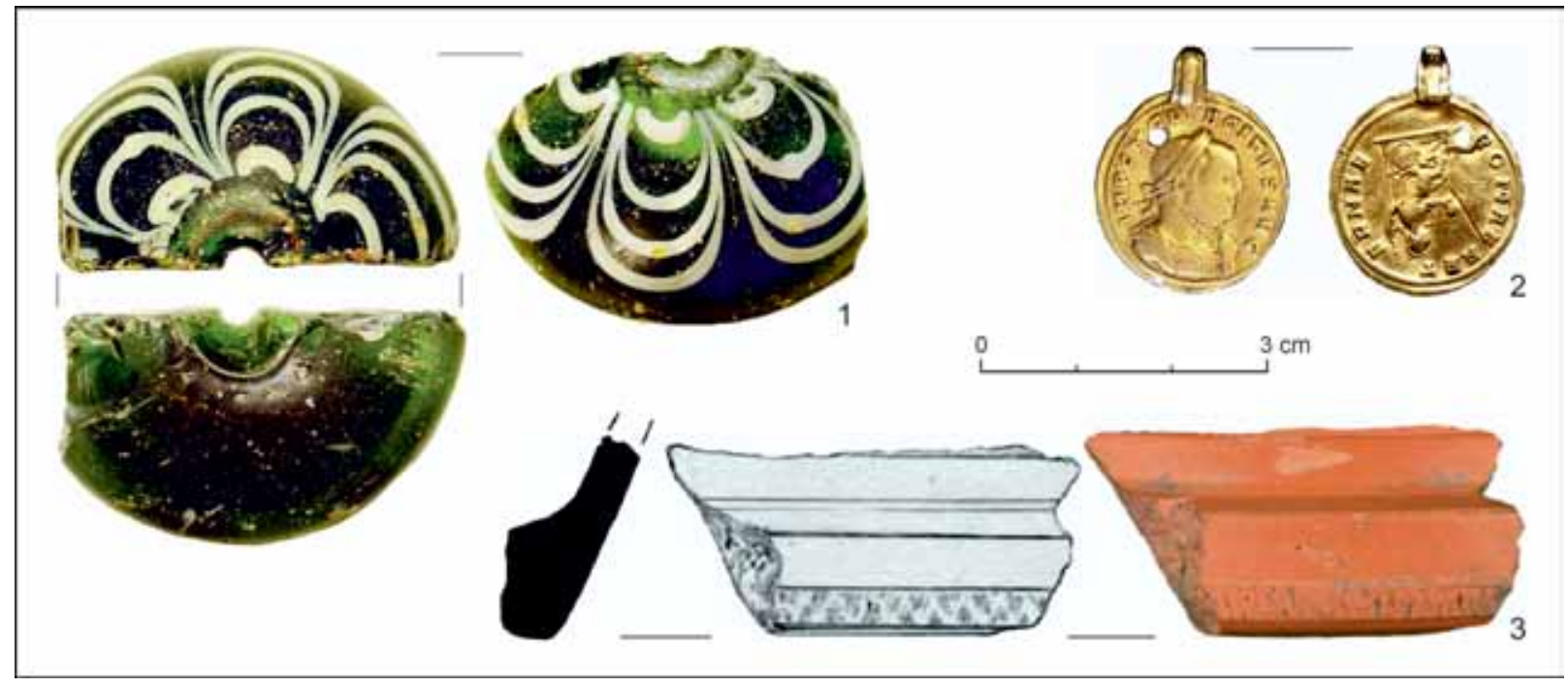

Fig. 3. Region of the Sacz Basin. Artifacts from the third century AD. 1 - Łukowica, Limanowa district, site 5 (photo B. Urbański); 2 - Gostwica, Nowy Sącz district (photo B. Urbański); 3 - Stronie, Limanowa district, site 47 (photo K. Mazur).

site 16, a fragment of a vessel manufactured in Rheinzabern was found (Parczewski 1996, 265, fig. 9), a fragment originating from Pfaffenhofen workshop (Fig. 3: 3) was discovered in Stronie, Limanowa district, site 47, at the borderlands of Beskid Wyspowy and the Sącz Basin (Przychodni/Tunia 2019, 261, fig. 3.1), and another sherd originating from that workshop was found in Beskid Mały, in Skawce, Wadowice district, site 4 (Przychodni/Tunia 2019, 265). The presence of products of the Pfaffenhofen workshop testify to contacts between the region and the Roman provinces during the rule of the Severan dynasty.

The vast majority of the sites known today from the Polish Carpathians are settlements. From the period discussed here only one small cemetery is known, in Rajbrot, Bochnia district, on the northern slopes of the Carpathians. It is a layered cremation cemetery, dated to the early phase of the Migration period (Fig. 4: 1-5; Biborski/Zagórska-Telega 2008, 87-96; 2009, 429-440). In this context it is also worth mentioning an elite "princely" burial from Poprad-Matejovce, Poprad district, in the upper Poprad River basin - not very far away from the area discussed here. The burial has been dated to the close of the $4^{\text {th }}$ century based on a coin issued by Emperor Valens in 375 AD (Lau 2013, 16-19; Lau/Pieta 2010, 343-364; 2017, 255-265; Pieta 2009, 107-122). These two discoveries exhaust the short list of Carpathian sepulchral sites from the period in question.

The new wave of settlers who arrived in the Beskid zone had to adjust their economic behaviours to the mountainous environment. Analysis of the Late Roman and Early Migration period settlement network in the Polish Carpathians shows that people inhabiting these areas had deep understanding of the natural environment and were capable of making maximum use of it. Settlement sites from the discussed period were located in highly characteristic places. They can often be found in higher locations: on watersheds and on local plateaus in upper sections of mountain slopes (Fig. 5: 1, 2). In broad valleys of large rivers, however, they occupied the edges of higher terraces (Fig. 5: 3, 4). Such a pattern of site location can be observed throughout the entire Beskid zone, including the mountain ranges of Beskid Sądecki, Beskid Niski, and Niskie Bieszczady (Madyda-Legutko/Tunia 2008). These high-altitude sites were typically small, single-household settlements, while those occupying edges of overflowing river terraces were large settlements with complex build-up (Barłowska 1984; Bulas et al. 2019). The highest located Carpathian sites were recorded around $600 \mathrm{~m}$ a. s. 1. in Poland (Piwniczna, Nowy Sacz distr. Madyda-Legutko/Tunia 1980; 2008, fig. 6), and 800 m a. s. l. or even higher in Slovakia (Ostrá Skala Mt. in Vyšný Kubín, Dolný Kubín distr. - Čaplovič 1976, 78-82; Hrdoš Mt. on the border between Žaškov, Dolný Kubín distr. and Komjatna, Ružomberok distr. - Lofajová-Danielová/Furman 2019, 269-281; Liptovský Ján, Liptovský Mikuláš distr. - Pieta 1992, 86, 87).

It can be thus reasonably assumed that the basic units in the Carpathian settlement network during the Late Roman and Early Migration periods were single-household settlements occupying openings scattered in mixed deciduous (Tilio-Carpinetum) and oak-pine (Pino-Quercetum) forests. They were accompanied by large settlements in broad river valleys, situated in safe locations above the flood plain, on the 


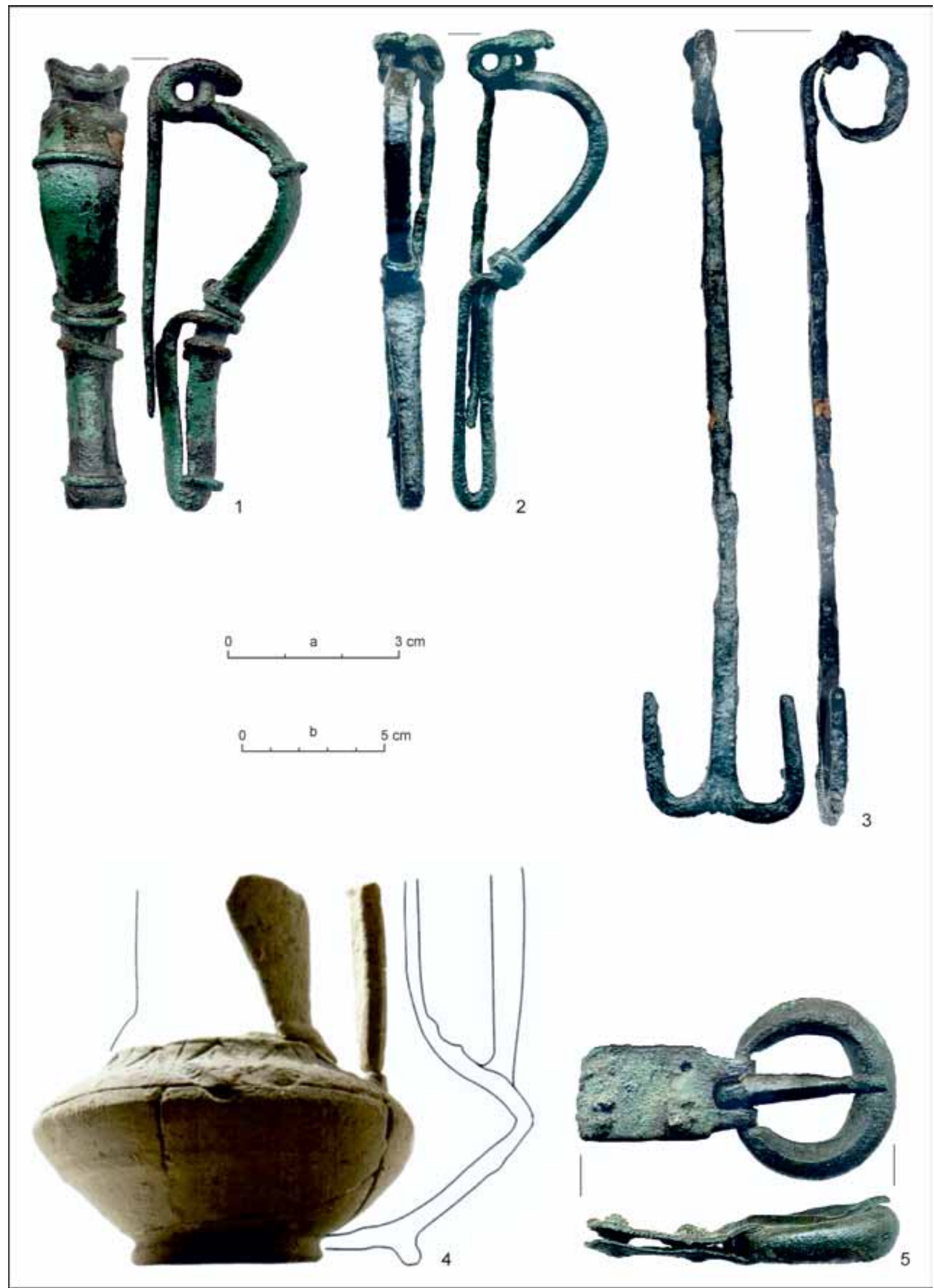

Fig. 4. Rajbrot, Bochnia district, site 1. Selection of the artefacts from the Migration period cemetery (prepared by U. Bąk). Scale: $a-1-4 ; b-5$. 

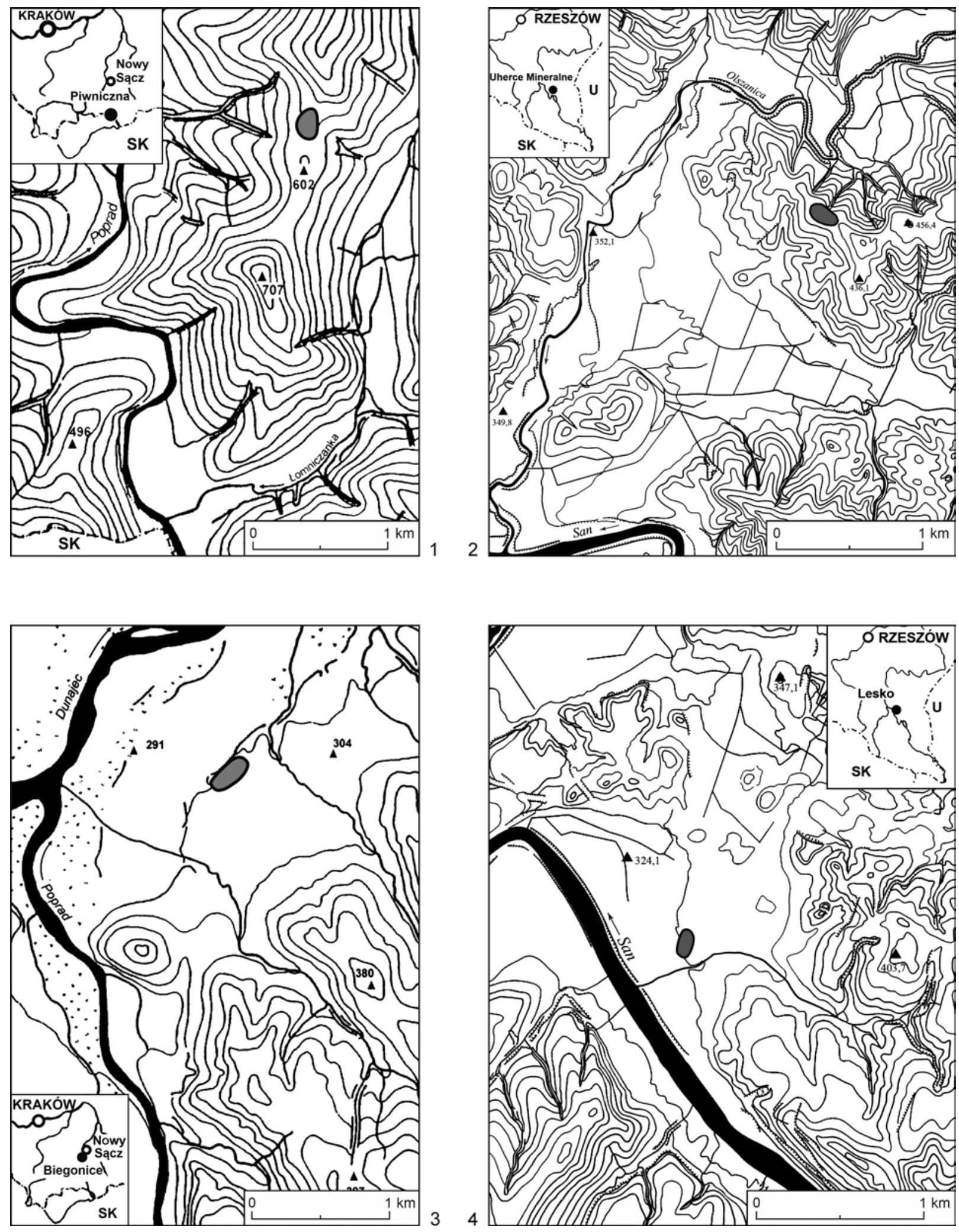

Fig. 5. Location of the sites from the Late Roman and Early Migration periods. 1 - Piwniczna, Nowy Sącz district, site A; 2 - Uherce Mineralne, Lesko district, site 17; 3 - Nowy Sacz-Biegonice, Nowy Sacz district, site 20; 4 - Lesko, Lesko district, site 4 (Madyda-Legutko/Tunia 2008). 


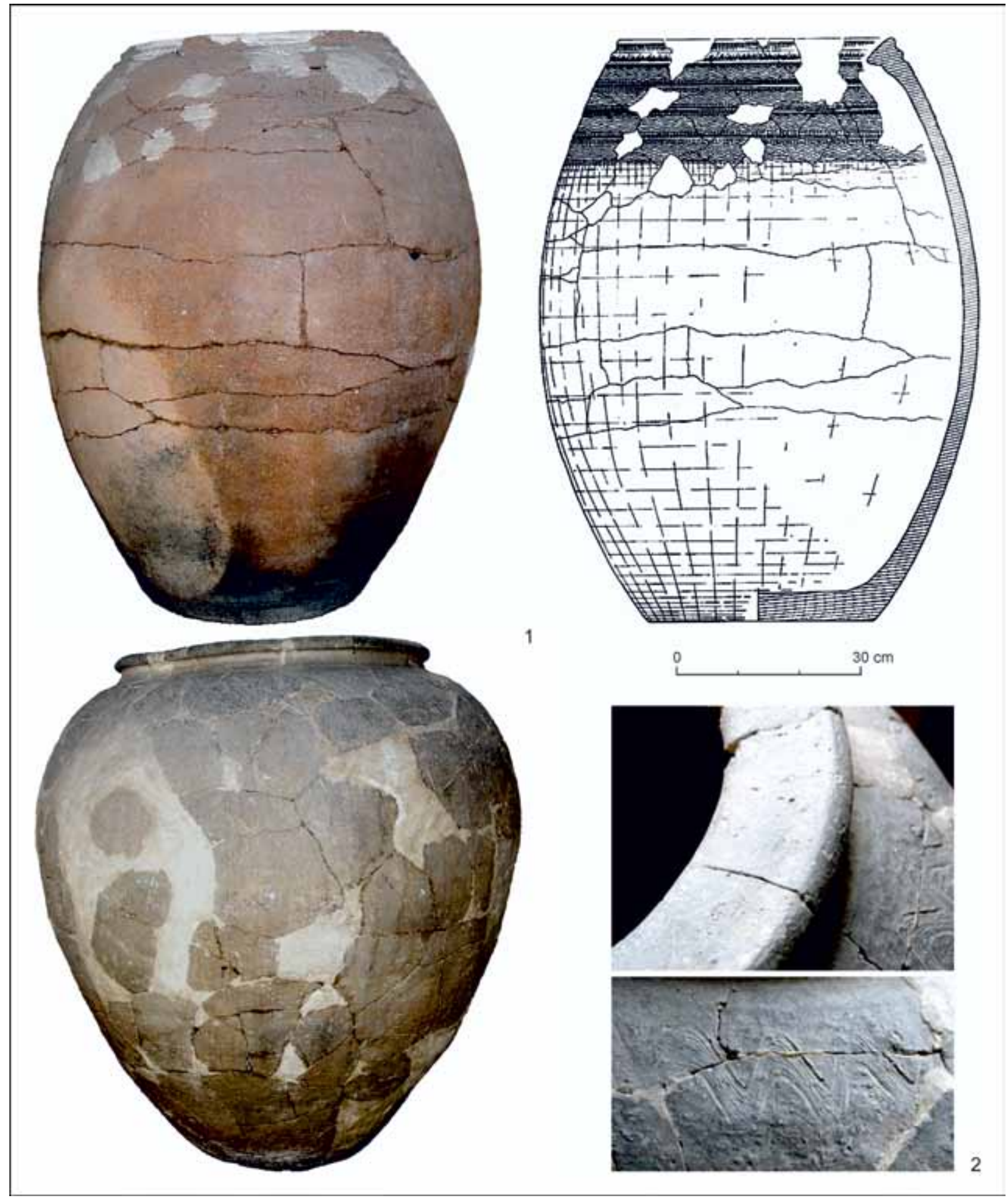

Fig. 6. Rytro, Nowy Sącz district, site A. Storage vessels of the Krausengefäß type. Photo K. Tunia.

edges of river terraces. In terms of the economic model, these communities relied on agriculture - cultivation and processing of cereals - and probably animal husbandry (Tunia 1986; 1989; 2004).

Studies on the settling of mountainous areas have shown that, due to a combination of environmental factors (hypsometry and lay of land, soil, hydrology, climate, flora, and fauna), the locations best suitable for permanent human occupation and economy are those situated higher (Tunia 1989). The upper limit of the zone suitable for settlement in the West Carpathians is nowadays around $700 \mathrm{~m}$ a. s. 1., and it must have been higher in the Subboreal period when the climate was warmer than today. 
An important question, one that still requires further research, is that of the ethnic structure of the community inhabiting the discussed part of the Carpathians at that time. In this connection, it is worth noting a significant representation of elements originating from other regions of Central Europe (the Carpathian Basin in particular), and from Eastern Europe in the material culture. The proportion of such elements is notably higher than in "classic" Przeworsk culture assemblages of that era. In light of the above, distinguishing the North Carpathian group as a cultural phenomenon - of as yet unknown range - characteristic of the West Carpathian zone seems to be a well-justified idea and a promising direction for future research.

Ceramic assemblages retrieved from the Polish and Slovak Carpathians during excavations and surface surveys comprise both hand- and wheel-made vessels. The latter are represented in Carpathian settlements with varying frequency and show certain local features (Madyda-Legutko 2011, 295-306).

One well-represented group are large storage vessels with broad rim, known as Krausengefäß. They differ among themselves in terms of size, proportions, and form of the rim. They are known from settlement sites throughout the Polish (Fig. 6: 1, 2; 9: 3-5; 10:1) and Slovak Carpathians (Giertlová-Kučerovál Soják 2005, fig. 8: 7, 8; 9: 1, 2; 14: 2, 5-7; Madyda-Legutko 1995, list V.1; map 6; 1996, 85-89, fig. 8: 1-15; Pieta 1991, fig. 5: 10, 11; Wilk 2005, 340-342, fig. 1). A vessel from site C in Moszczenica Wyżna, Nowy Sącz district, in Beskid Sądecki, deserves particular attention here: it was intentionally embed in the ground near a dwelling and household features (Fig. 6: 1; Madyda-Legutko 2011, fig. 6: 1a-c; Madyda-Legutko/Tunia $1978,122,123$, fig. 13). Intentional digging of storage vessels has also been confirmed in other settlements in the West Carpathians: at site 1 in Ujazd, Jasło district, in the Ciężkowice Foothills (Pohorska 1978, fig. 5: 11), and in Świerchowa, Jasło district, in the Jasło-Sanok Basin (Szałapata 1966, 38, fig. 4a).

Pottery recovered from settlement sites on the Poprad River in Beskid Sądecki reveals some unique characteristics: among the vessels are poorly fired pots made from ceramic mass with mineral temper, which bear traces of turning on a slowly rotating wheel. These pots have brown surfaces decorated with single or multiple wavy lines, and the shape of the rim varies (Fig. 7: 1-3; Madyda-Legutko 1996, 81, pl. XXII: 1-14; 2011, fig. 5: 1a, b, 2, 3, 6-8; Madyda-Legutko/Tunia 1978, 133, fig. 8b; 9g; 1993, 50-53, fig. 9: 1-30; pl. XI: b; XIII: i; XVI: c; XXXVII: a). Such vessels find no analogy so far in other sites from Poland's Beskid zone, while they refer in terms of style to vessels discovered on the upper Poprad River, in a pottery kiln in Kežmarok-Vrbov at Vrbovský Lesík site, Kežmarok district (Giertlová-KučeroválSoják 2005, fig. 7: 2, 5).

The inhabitants of settlements in Beskid Sądecki were not an isolated population: they maintained contacts with the northern, mountainous part of Slovakia, and above all with the Carpathian Basin, the Danube River basin, and the post-Chernyakhov culture milieu. This is confirmed by single wheel-made vessels discovered in the above settlements. These vessels include jugs with cylindrical necks, the handle bent at a right angle, and with a groove inside, known from settlements at Rytro site A and Moszczenica Wyżna site A, both in Nowy Sącz district (Fig. 8: 1-3; Madyda-Legutko 1996, 82, pl. XXIII: 1-3; 2011, fig. 7: 5-7; Madyda-Legutko/Tunia 1978, 130, fig. 9d-f; 1993, 62-64, pl. XIX: a; XX: a). Such forms are known from northern Slovakia as well (Fig. 8: 4-6). Jugs with handles formed in this manner are believed to be associated with nomadic tribes, the Huns in particular (Madyda-Legutko 1996, 82, with older literature; Vaday 1994, 105-114, pl. I: 1-14). A two-handled vessel from Rytro, with both surfaces covered with a thin layer of brick-red engobe and decorated with a burnished pattern of hanging triangles, refers in style to two-handled vessels known from the Chernyakov-Sîntana de Mureš culture (Fig. 7: 4; Madyda-Legutko/ Tunia 1993, 47-49, pl. XXXIII: a; Pawlikowski 1993, 159-161). The ornamentation of a jug from Podegrodzie, Nowy Sącz district (Fig. 7: 5) ${ }^{6}$ is another reference to this style. Two other vessels found in Rytro: a wheel made bowl (Fig. 8: 8) and a handmade vessel with stamped decoration (Fig. 8: 9), are unique finds (Madyda-Legutko 2011, fig. 5: 2-2a; Madyda-Legutko/Tunia 1993, 65, 69, fig. XI: a; XII: b). Also of note is a fragment of a wheel-made bucket-shaped vessel from Rytro (Fig. 8: 7), a reference to vessels known from layered cemeteries of the Dobrodzień type (Madyda-Legutko/Tunia 1983, 33, pl. XXXVI: e). In terms of chronology, the above vessels represent the latest ceramic forms in the discussed settlements.

The research conducted in the Polish Carpathians in recent years has filled some more gaps in the picture of human activity in the Beskid zone during the Late Roman and Early Migration periods. The archaeological fieldworks preceding the construction of the Świnna Poręba reservoir on the Skawa River (on the borderlands of Beskid Mały and Beskid Makowski) involved, among other things, exploration of Late Roman and Early Migration period settlement sites in Skawce (site 4) and Zagórze (sites 8 and 14), both in Wadowice district (Valde-Nowak 2014, 484-487). In Skawce, a paleochannel of a small river was discovered at the foot of Mucharz hill, with traces of hearths, stone pavements, and undetermined pits re-

\footnotetext{
6 Collection of the Archaeological Museum in Kraków.
} 


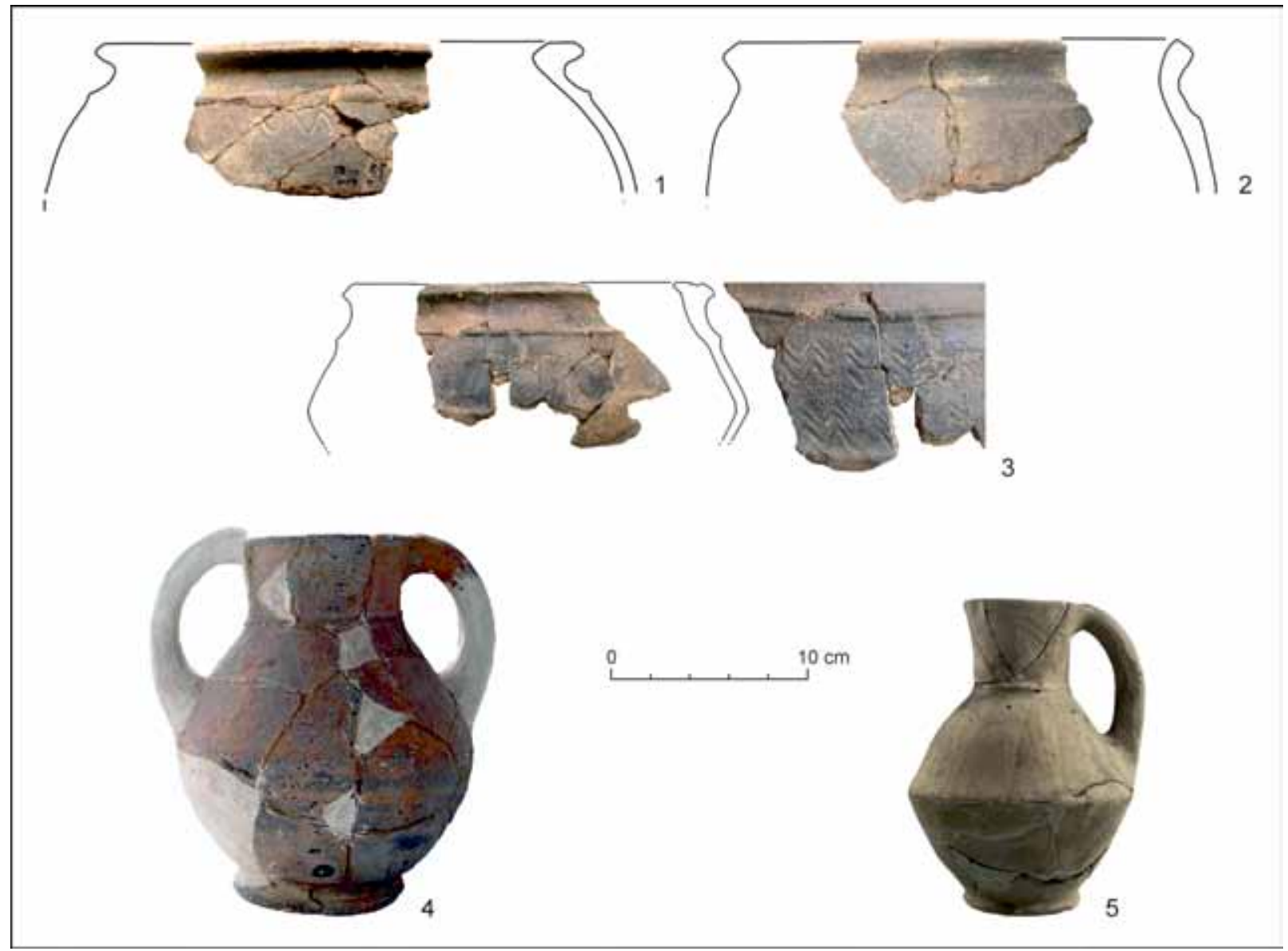

Fig. 7. Pottery from Beskid Sądecki and Sącz Basin. 1, 2, 4- Rytro, Nowy Sącz district, site A (Madyda-Legutko/Tunia 1993, pl. XVI: c; XXXVII: a; photo M. Grygiel); 3 - Moszczenica Wyżna, Nowy Sącz district, site A (Madyda-Legutko/Tunia 1998, fig. 9: g; photo M. Grygiel); 5 - Podegrodzie, Nowy Sącz district (photo A. Susuł).

corded along it.7 The cultural layer yielded human bones, a buckle with a thickened frame, and two glass beads (Valde-Nowak 2014, 484, 486, fig. 2). The sites in Zagórze revealed remains of sunken houses (site 8) and rectangular hearths (site 14), characteristic of the Roman Period (Valde-Nowak 2014, 486, fig. 3: a, b; 4). In terms of pottery, the sites on the Skawa River produced handmade vessels (Fig. 9: 1), a large series of wheel-made vessels, as well as fragments of storage vessels of the Krausengefäß type (Fig. 9: 4, 5).

Intensive occupation in the upper basin of the Wisłoka River during the Younger/Late Roman - Early Migration periods has been confirmed by settlement sites excavated in Lipnica Dolna site 8 (Kłosowicz/ Leszczyński 2017) and Ujazd, site 1, both in Jasło district (Pęcherek 2018; Pohorska 1978), and by sites identified during surface surveys. The two settlements mentioned above lie within the Ciężkowice Foothills, to the south of Mount Liwocz. In Lipnica Dolna, a pottery kiln was uncovered with no traces of a grate and no constructional elements potentially supporting it ${ }^{8}$ (Kłosowicz/Leszczyński 2017, 463-481, fig. 5; 7; photos 1, 2; pl. III: 1-11; IV: 1-12; V: 1-12; VI: 1-12; VII: 1-12; VIII: 1-13; IX: 1-12; X: 1-7). It was assigned to single-chamber kilns of type D in J. Henning's (1977) classification, which are most common in the $3^{\text {rd }}$ and $4^{\text {th }}$ centuries. Both the main chamber and the entrance pit contained large amounts of sherds belonging to storage and wheel-made vessels. The settlement in Ujazd, in turn, is known from rescue excavations only (Pohorska 1978). A re-analysis of the distribution of archaeological features in the site suggests the presence of a post-built structure there (Pecherek 2018). Apart from the above-mentioned storage vessel dug into the ground, the settlement yielded large series of wheel-made (Fig. 9:3) and hand-made (Fig. 9: 2) pottery.

\footnotetext{
7 The authors would like to thank P. Micyk and I. Doniec for making the materials available.

8 One kiln has been published (Kłosowicz/Leszczyński 2017). The information about the another kilns we owe to T. Leszczyński.
} 


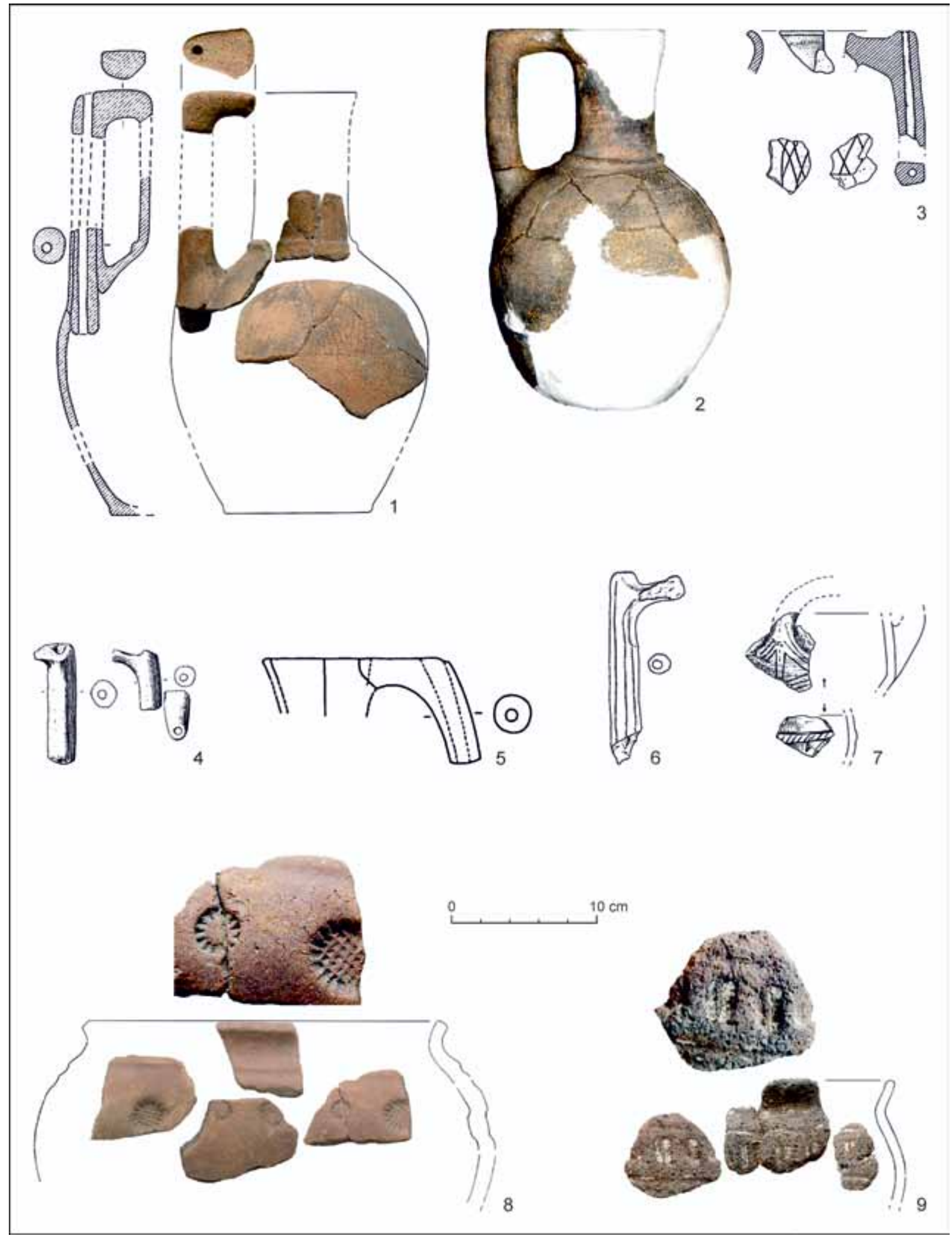

Fig. 8. Pottery. 1-3, 7-9 - pottery from the Polish Carpathians, 4-6 - pottery from the Slovak Carpathians. 1, 2 - Rytro, Nowy Sącz district, site A (Madyda-Legutko/Tunia 1993, pl. XIX: a; XX: a; photo M. Grygiel); 3 - Moszczenica Wyżna, Nowy Sącz district, site A (Madyda-Legutko/Tunia 1978, fig. 9: d-e); 4 - Vrbov, Kežmarok district (Pieta 1987, fig. 3: 12, 13); 5 - Liptovský Ján, Liptovský Mikuláš district (Pieta 1991, fig. 5: 2); 6- Ostrovany, Sabinov district (Lamiová-Schmiedlová/Tomášová 1999, pl. XII: 8); 7-9 - Rytro, Nowy Sącz district, site A (Madyda-Legutko/Tunia 1993, pl. XI: a; XII: b; XXXVI: e; photo M. Grygiel). 


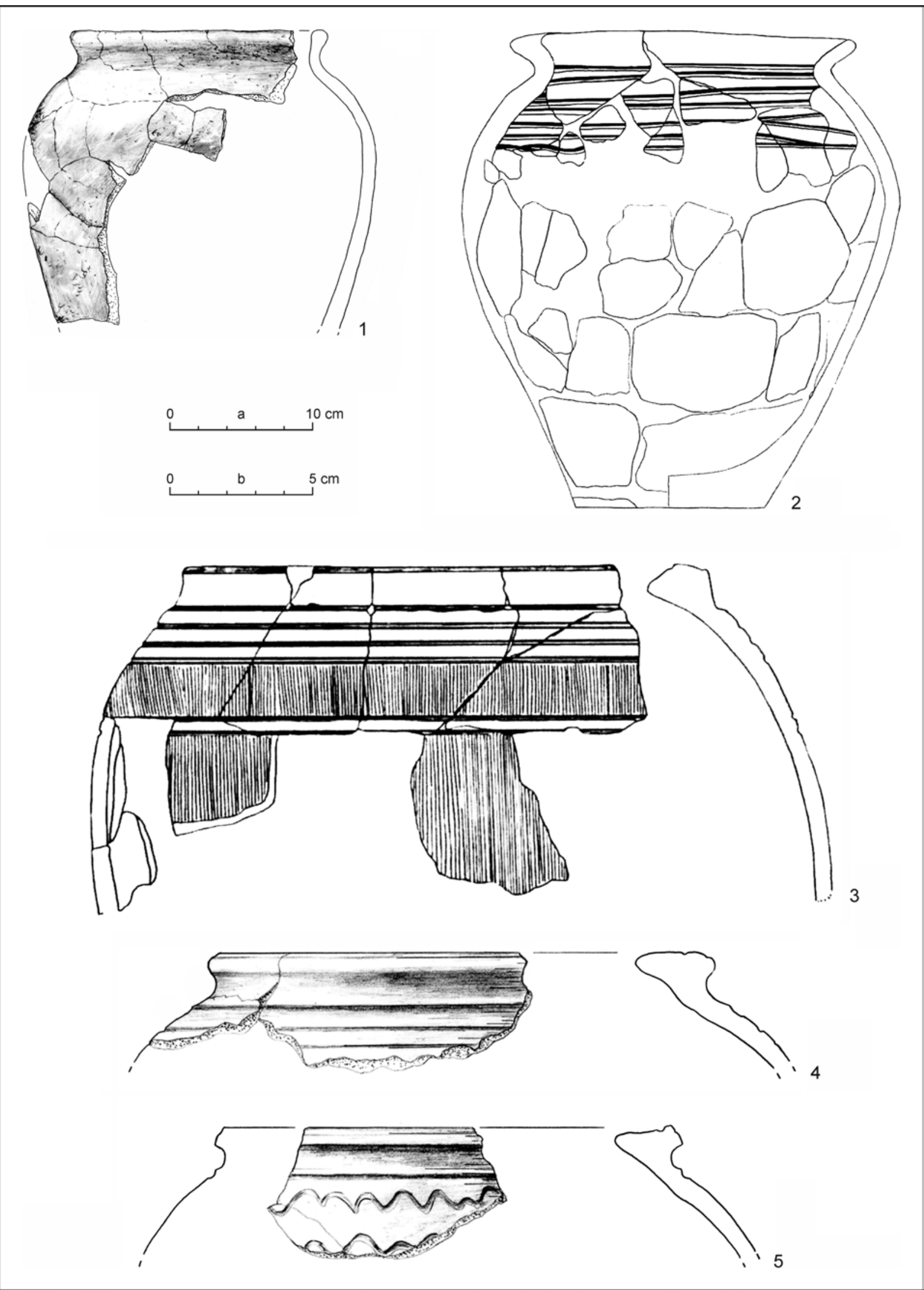

Fig. 9. Pottery from the Polish Carpathians. 1, 4, 5-Skawce, Wadowice district, site 4 (Doniec, in preparation); 2, 3 - Ujazd, Jasło district, site 1 (Pęcherek 2018). Scale: $a-1-3 ; b-4,5$. 


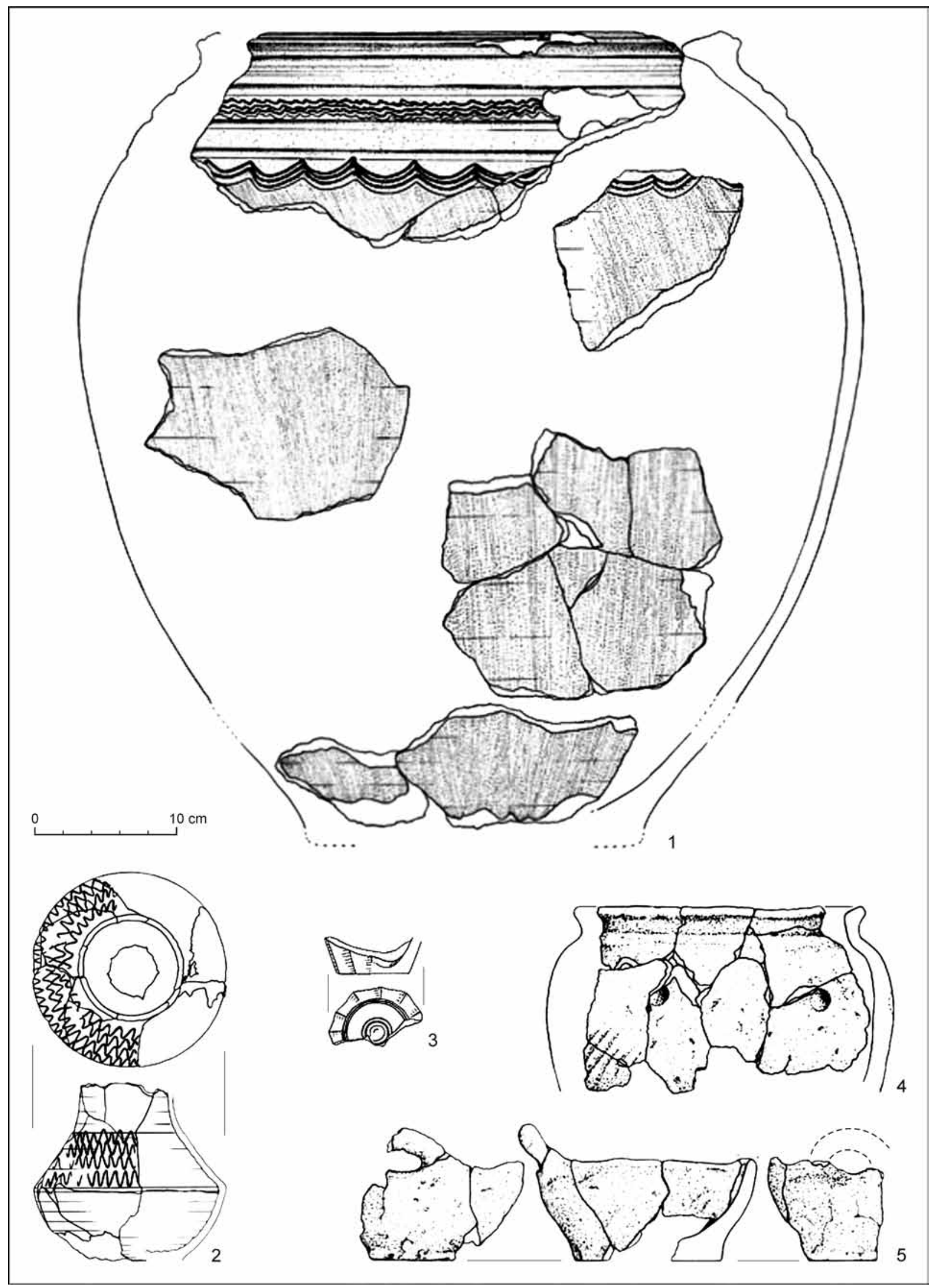

Fig. 10. Sanok, Sanok district, site 59-60. Selection of the pottery from the settlement (Bulas et al. 2019, fig. 15: 2, 8; 16: 1; 17: 4, 6). 
A settlement at site 59-60 in Sanok, in the southern part of the Sanok Basin, produced important information concerning spatial layout of settlement sites functioning in the Late Roman and Early Migration periods (Bulas et al. 2019, 55-81). Buildings formed three distinct concentrations within the site, which the authors of the research describe as household clusters. Apart from diverse post-built structures, each household comprised various other features including pits, hearths, pottery kilns, and clay pits (Bulas et al. 2019, fig. 9). In a natural depression in the central part of the settlement, four wells with wooden boardings and a pit interpreted as a flax rettery were uncovered. Standing out among a large series of pottery retrieved from the site, both wheel- (Fig. 10: 2) and hand-made (Fig. 10: 4), are a fragment of a polygonal vessel (Fig. 10: 3) and a fragment belonging to a hand-made bucket-shaped vessel (Fig. 10: 5). Storage vessels of the Krausengefäß type are well-represented, as well (Fig. 10: 1; Bulas 2019, fig. 2: 2-4; Bulas et al. 2019, fig. 12: 3-5; 15: 1-12; 16: 1-7; 17: 1-11). The settlement in Sanok dates within the Late Roman period - Early Migration period. A radiocarbon date obtained from a plank from one of the wells indicates that the well functioned in the first half of the $5^{\text {th }}$ century. Such chronology seems to be corroborated by the discovery of a fragment of a vessel interpreted by the explorers as belonging to a Hunnic cauldron (Fig. 11: 7; Bulas 2019, 63, 64, fig. 3: 4; Bulas et al. 2019, 77, fig. 18: 3). This find is unambiguous proof of contacts between the region and the Carpathian Basin.

As mentioned, a similar pattern of spatial organization was recorded at the site 4 in Lesko, on the San River where five household clusters were identified, consisting of alleged above-ground or sunken dwellings accompanied by pits, hearths, and concentrations of daub (Barłowska 1984). Among the artefacts discovered there, of particular note are small fragments of two glass vessels (Barłowska 1984, 60, 70, fig. 6; pl. III: 9). One of them possibly belongs to a vessel decorated with rhombi (Fig. 11: 3; Bulas 2019, 59, 60, fig. 1: 2; Maczyńska 1999, 27) ${ }^{9}$, and the other is a fragment of a light-green beaker decorated with ovals, of type E 226 or E 228 (Fig. 11: 4; Bulas 2019, 59, fig. 1: 1; Eggers 1951, 180, 181; Madyda-Legutko 1998, 31, fig. 2: 7; Rau 1972, 127, 128, fig. 15; 17-21). The former vessel, probably of Pannonian origin, should be dated to the close of the $4^{\text {th }}$ century - first decades of the $5^{\text {th }}$ century (cf. Godtowski 1991, fig. 6: 5; 1995, 158, fig. 8: 3 , 4), while the latter should be linked with the East European range of glass beakers with cut decoration (Gavritukhin 2011, 39-69, fig. 1; Rau 1972, 167, fig. 52).

As mentioned above, artefacts recovered from settlements situated in the Polish Carpathians include primarily pottery. Unlike in settlement sites from the mountains of Slovakia, artefacts like metal dress items and weapons are only represented here by single finds, which currently seem to concentrate in the mountain section of the San River valley. Dress items attributable to phase C3-D, which means to the close of the Roman period and the early phase of the Migration period, include above all bronze buckles with strongly thickened oval frames, and their fragments, known from Sanoczek, Sanok district (Fig. 11: 5; Bodzek/Pohorska-Kleja 2011, 156, pl. I: 2; Bulas 2019, 68, fig. 3: 2), Międzybrodzie, Sanok district (Bodzek/ Fedyk/Kotowicz 2019, 276; fig. 11: 7) ${ }^{10}$, and Sanok-Biała Góra, site Zamczysko (Bodzek/Fedyk/Kotowicz 2019, 276). A bronze brooch with full catch plate and a head plate, from Pakoszówka, Sanok district, site 33, also belongs to the discussed period (Bulas 2019, 68, fig. 3: 3). In the Ciężkowice Foothills, a buckle with stamped decoration in the Untersiebenbrunn style was recovered from the Wisłok River near Strzegocice, Dębica district. The buckle features silver inlays on its frame, and is characteristic of a horizon described as Strzegocice-Tiszaládány-Kercz (Fig. 11: 6; Koch 1999, 172, fig. 13: 1; Madyda-Legutko 1978). Such artefacts are typical of stadium D2 of the Early Migration period in J. Tejral's approach (Tejral 2011, 174-181). In Bieszczady Mts, a spatha sword from phases C2-D, representing type Ejsbøl-Sarry according to Marcin Biborski, was retrieved from the San River near Solina village in Lesko district (Fig. 11: 1; Biborski/Ilkjær 2006, 259-271; Bodzek/Fedyk/Kotowicz 2019, 276; Kotowicz/Fedyk 2008, 113-117, fig. 2; 3: 1). Analogical swords are known from aquatic contexts. Two such specimens recovered from the Dunajec River in two separate places in the Carpathian Foothills (Fig. 11: 2; Biborski 1995, 13, 14, fig. 1; 2; Kotowicz/Fedyk 2008, 115, 116).

Both in the Polish and Slovak Carpathians, settlement of the North Carpathian group correlates with the close of the Roman period and the early phase of the Migration period, which is with phases C3-D1 and D2 in Jaroslav Tejral's periodisation. In a more recent approach to the chronology of the Migration period, this settlement is dated to AD 380-390/400-440/450 (Tejral 2011, 15-24). It should be emphasised that the functioning of the settlements of the North Carpathian group falls to a time which in Central Europe is marked by great ethnic shifts, the disintegration of old cultural-settlement structures, and the domination of Hunnic tribes. North Carpathian group is assumed to have vanished before the mid- $5^{\text {th }}$ century (Pieta 2002, 18), as was also the case with other cultural structures within Central European Barbaricum.

\footnotetext{
9 R. Madyda-Legutko (1998, 31, fig. 2: 8) interpreted this artefact as a cup fragment of type Choszczno E 199, 200.

10 Archives of the Historical Museum in Sanok. Photo by Piotr N. Kotowicz.
} 

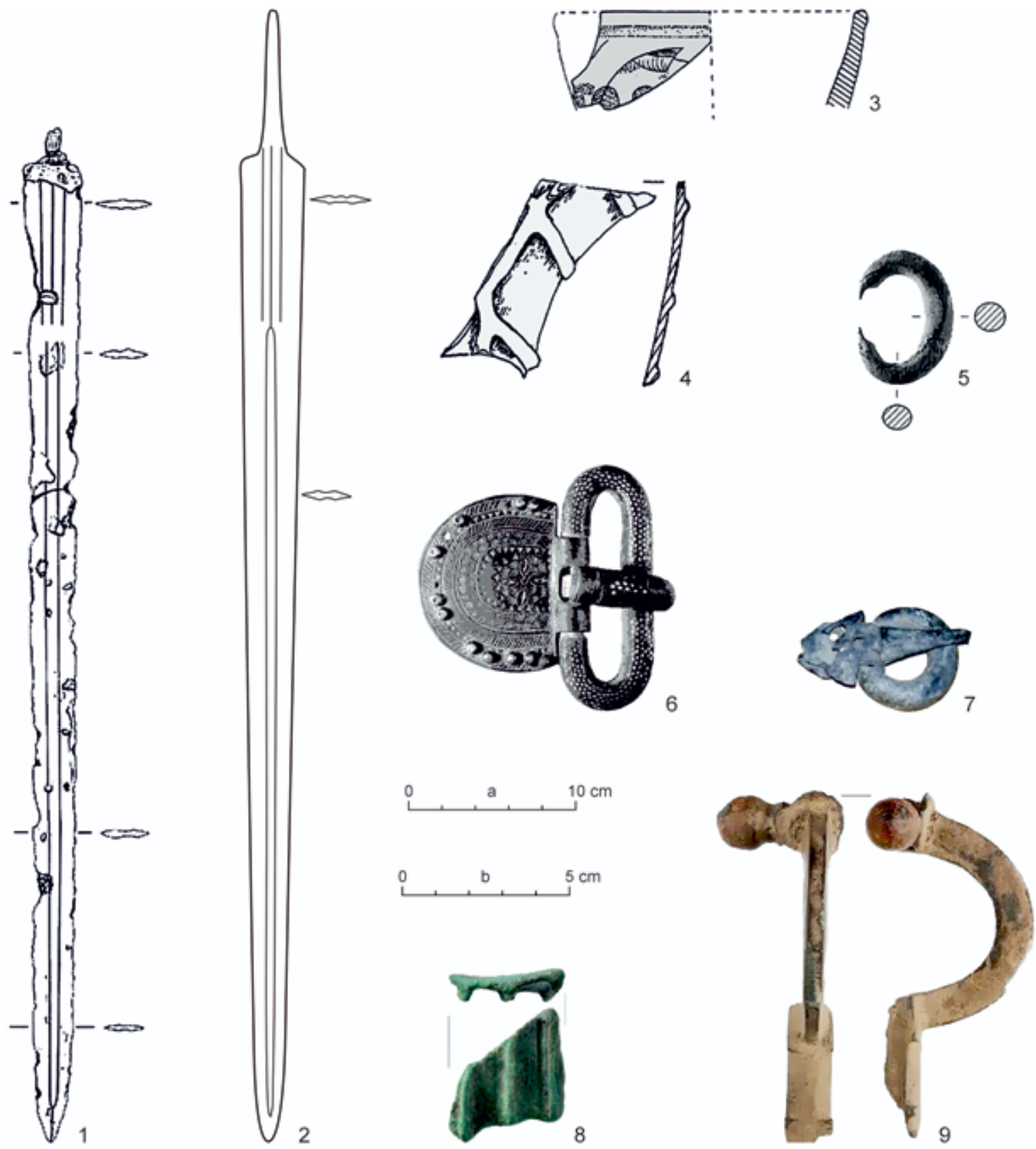

Fig. 11. Metal and glass artefacts from the Polish Carpathians. 1 - Solina, Lesko district (Kotowicz/Fedyk 2008, fig. 2); 2 - Ostrów, Tarnów district (Biborski 1995, fig. 2); 3, 4 - Lesko, Lesko district, site 4 (Madyda-Legutko 1998, fig. 2: 7, 8); 5 - Sanoczek, Sanok district (Bodzek/Pohorska-Kleja 2011, pl. I: 2); 6 - Strzegocice, Dębica district (Madyda-Legutko 1978, fig. 1; photo K. Pollesch); 7 - Międzybrodzie, Sanok district (Bodzek/Fedyk/Kotowicz 2019, 276; photo - archive of the Historical Museum in Sanok); 8 - Sanok, Sanok district, site 59-60 (Bulas et al. 2019, fig. 18: 3); 9 - Pakoszówka, Sanok district, site 33 (Bulas 2019, fig. 3: 3). Scale: a - 1, 2; b-3-9.

The settlements most likely ceased to exist in a violent manner, which is suggested in the archaeological record by traces of fires, clearly discernible for example in Rytro, Nowy Sacz district (Madyda-Legutko/ Tunia 1993, 37) and Lesko, Lesko district (Barłowska 1984, 74). The collapse of settlement structures in the discussed period is also evident in the palinological record. A pollen diagram from Wołosate in Bieszczady district shows the regeneration of forest and a drop in human activity indicators. This is linked with the settlement regress in the Migration period (Ralska-Jasiewiczowa 1980, 158). 


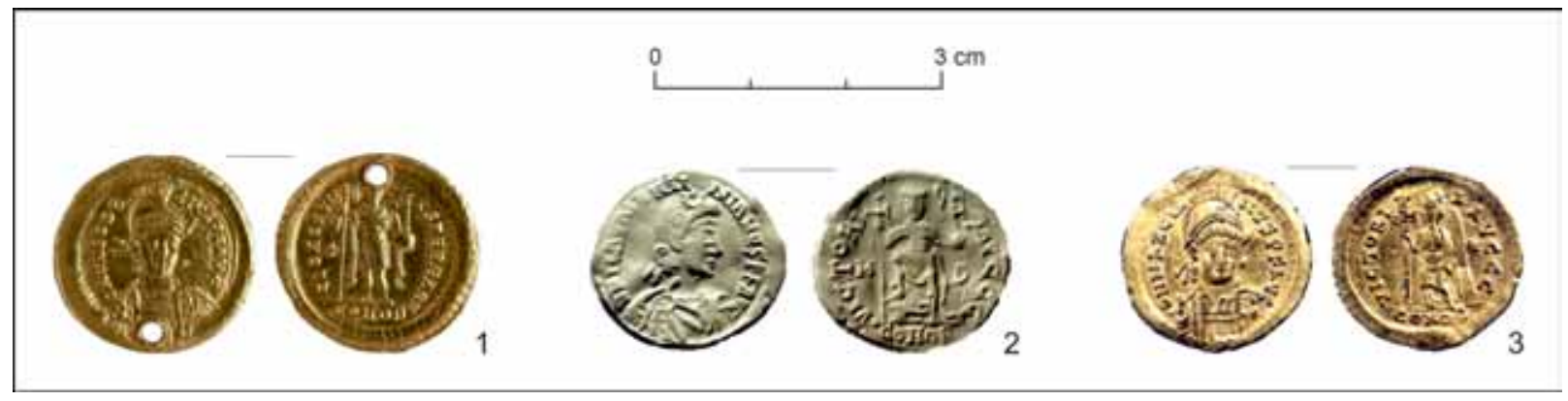

Fig. 12. Golden solidi from the Polish Carpathians. 1 - Prełuki, Sanok district (Bodzek/Fedyk/Kotowicz 2019, fig. 1: 2); 2 Prusiek, Sanok district, plaster cast (Bodzek/Pohorska-Kleja 2011, pl. I: 1); 3 - Sławęcin, Jasło district (Bodzek 2009, fig. 4: 7).

On the other hand, it is worth noting that discoveries of Late Roman coins in the Polish Carpathians, in particular in the upper San River basin, indicate that the region continued to be visited after the middle of the $5^{\text {th }}$ century as well. A solidus of Emperor Theodosius II (408-450) minted in Constantinople in 424-425 was found on the slopes of Skalisko Mt. (487 m a. s. 1.) in Prełuki, Sanok district, on the Osława River, a tributary to the San River (Fig. 12: 1; Bodzek/Fedyk/Kotowicz 2019, 269-284). From Prusiek, Sanok district, comes a solidus of Valentinian III (425-455), minted in Milan probably in 430-455 (Fig. 12: 2; Bodzek 2009, 185, fig. 4: 6; Bodzek/Pohorska-Kleja 2011, 154, pl. I.1). Two coins were found further to the west, on the Ropa River (a left-bank tributary to the Wisłoka River). The first, a bronze coin of Valentinian III (425-455), comes from Biecz, Gorlice district (Bodzek 2009, 179), and the second, a solidus of Eastern Roman Emperor Marcianus (450-457) found in Sławęcin, Jasło district (Fig. 12: 3), is the latest Roman coin found in the Polish Carpathians (Bodzek 2009, 187, fig. 4: 7; Skowronek/Ślawski 1966, 204). Late Roman solidus coins are believed to have been possibly inflowing into southern Poland, the Carpathians included, in the last third of the $5^{\text {th }}$ century (Bodzek/Fedyk/Kotowicz 2019, 275).

In this context, important questions emerge, namely who were the people who infiltrated the mountainous areas in the San River basin after the mid- $5^{\text {th }}$ century, and who caused the fires that ravaged settlement sites of the North Carpathian group? At the present stage of research, these questions are still a bit rhetorical.

A new cultural cycle began in the West Carpathians when Early Slavic settlement (linked with the socalled Prague cultural province) started to move into the southern basin of the Vistula River. According to the current state of knowledge and in light of the constantly growing body of evidence, concentrations of Early Slavic settlements can be identified on the San River not only in its middle course, but also further to the south, up the river, in the Dynów Foothills and as far as the Sanok Basin (Fig. 14; Parczewski 2003, 191-209; 2011, 97-106, fig. 3). Early Slavic settlements on the mountainous section of the San River, in the Dynów Foothills, reveal roughly square semi-sunken houses, typically with the remains of a heating device in the northern corner, which date to the $5^{\text {th }} / 6^{\text {th }}-7^{\text {th }}$ centuries (Parczewski 2011, 97). The largest number of such houses, as many as sixteen, were found in site 16 in Bachórz, Rzeszów district (Fig. 14; Parczewski 2003; 2011, 101), with two more found in site 11 in Dynów, Rzeszów district (Parczewski 2011, 101), and one in site 1 in Hłomcza, Sanok district (Muzyczuk/Pohorska-Kleja 1994, 61, fig. 4; Parczewski 2011, 101). Early Slavic materials have also recently been discovered at the borderlands between the Dynów and Przemyśl Foothills, in a settlement at Jabłonnica Ruska, Brzozów district, in site $1 .^{11}$

Further to the west, Early Slavic materials are unambiguously confirmed in the Sacz Basin on the Dunajec River: in site 9 at Podegrodzie, Nowy Sącz district (Madyda-Legutko/Tunia 1991, 83-93; 1992, 123-146). Early Slavic occupation is represented there by a unique cremation burial in urn of a male aged over 30 (Fig. 13: 2), and a pit a few metres away from the grave, in which many fragments of handmade vessels (Fig. 13: 3-5) were found along with a significant amounts of animal bones and plant remains (Madyda-Legutko/Tunia 1992, 126-133, 140-142, fig. 3-9).

Early Slavic occupation is also confirmed in the Spiš region in Slovakia (Fig. 14; Kučerová et al. 2012). Four sunken houses with stone stoves in the northern and north-western corners were discovered at Spišský Štvrtok, Levoča district, in site Pod Šibeničnou horou. The fills of the houses contained fragments of pottery and animal bones (Kučerová et al. 2012, 19-22, fig. 1-6). Another sunken house with

11 Information from Piotr N. Kotowicz, Historical Museum in Sanok. The field research of M. Mazurek. 


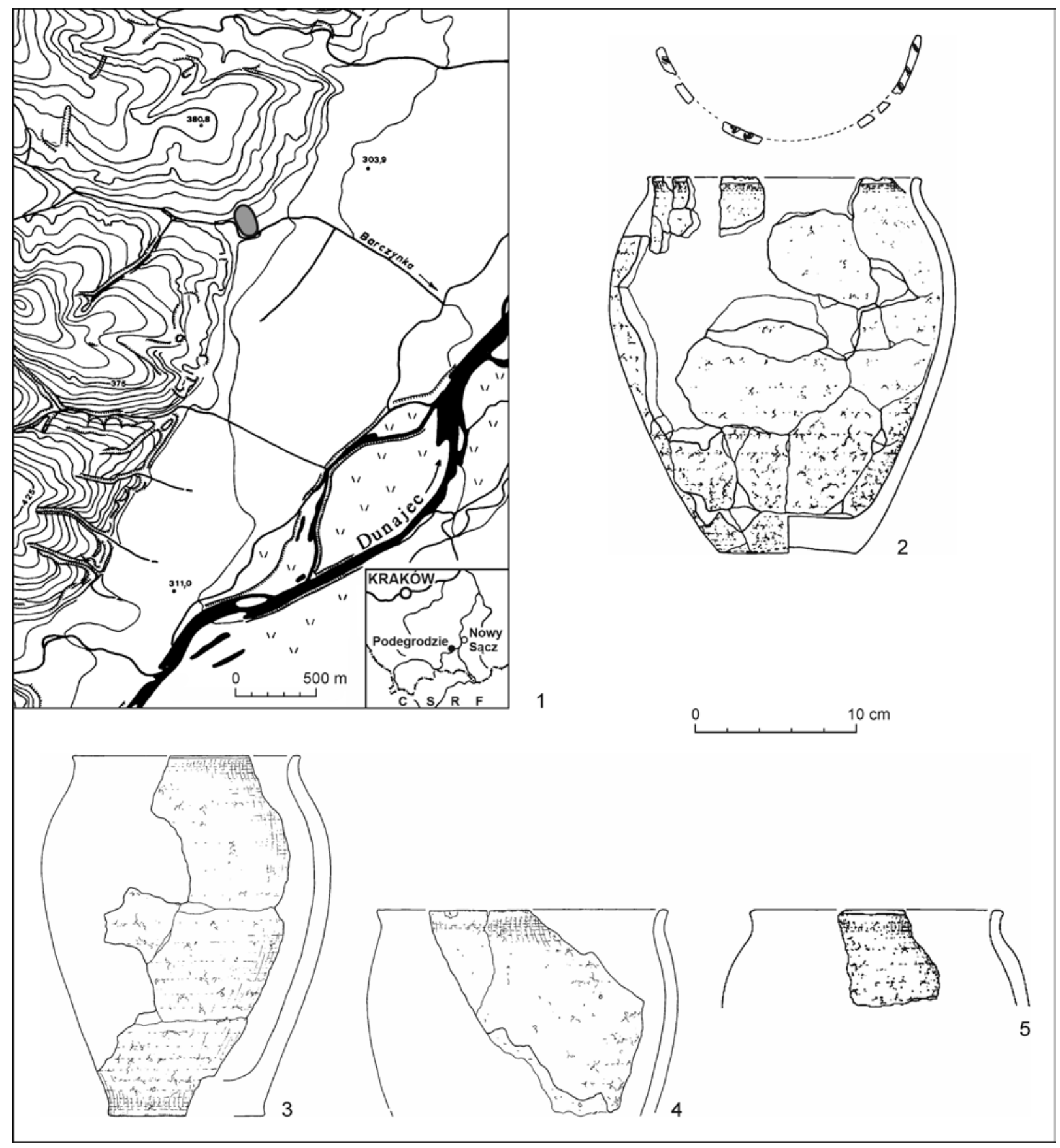

Fig. 13. Early Slavic finds from Podegrodzie, Nowy Sącz district, site 9.1 - location of the site; 2 - urn from the grave 1; 3-5 - pottery from the feature 26 (Madyda-Legutko/Tunia 1992, fig. 1; 4; 6; 7b).

a stove in the northern corner was found at Iliašovce, Levoča district, in site Za hostincom (Kučerová et al. 2012, 22, 23, fig. 7; 8). The chronological position of the above materials falls within phase Ib acc. to G. Fusek $(1994,101)$, which means the turn of the $5^{\text {th }}$ and $6^{\text {th }}$ centuries. In addition, Early Slavic materials have been mentioned at Žilina in north-western Slovakia (Fusek 1994, 266, 267).

It is worth noting that Early Slavic settlement sites in the Polish Carpathians were typically established in locations previously occupied by older, Roman period settlements (Bachórz, site 16, Jabłonnica Ruska, site 1, Hłomcza, site 1, Podegrodzie, site 9), although no higher than $350 \mathrm{~m}$ a. s. $1{ }^{12}$ It cannot be ruled out that early Slavs were deliberately choosing places familiar to them and which suited their needs.

12 M. Parczewski (1988, 63-68) noted a preference evident among the Slavs for lower parts of landscapes. 


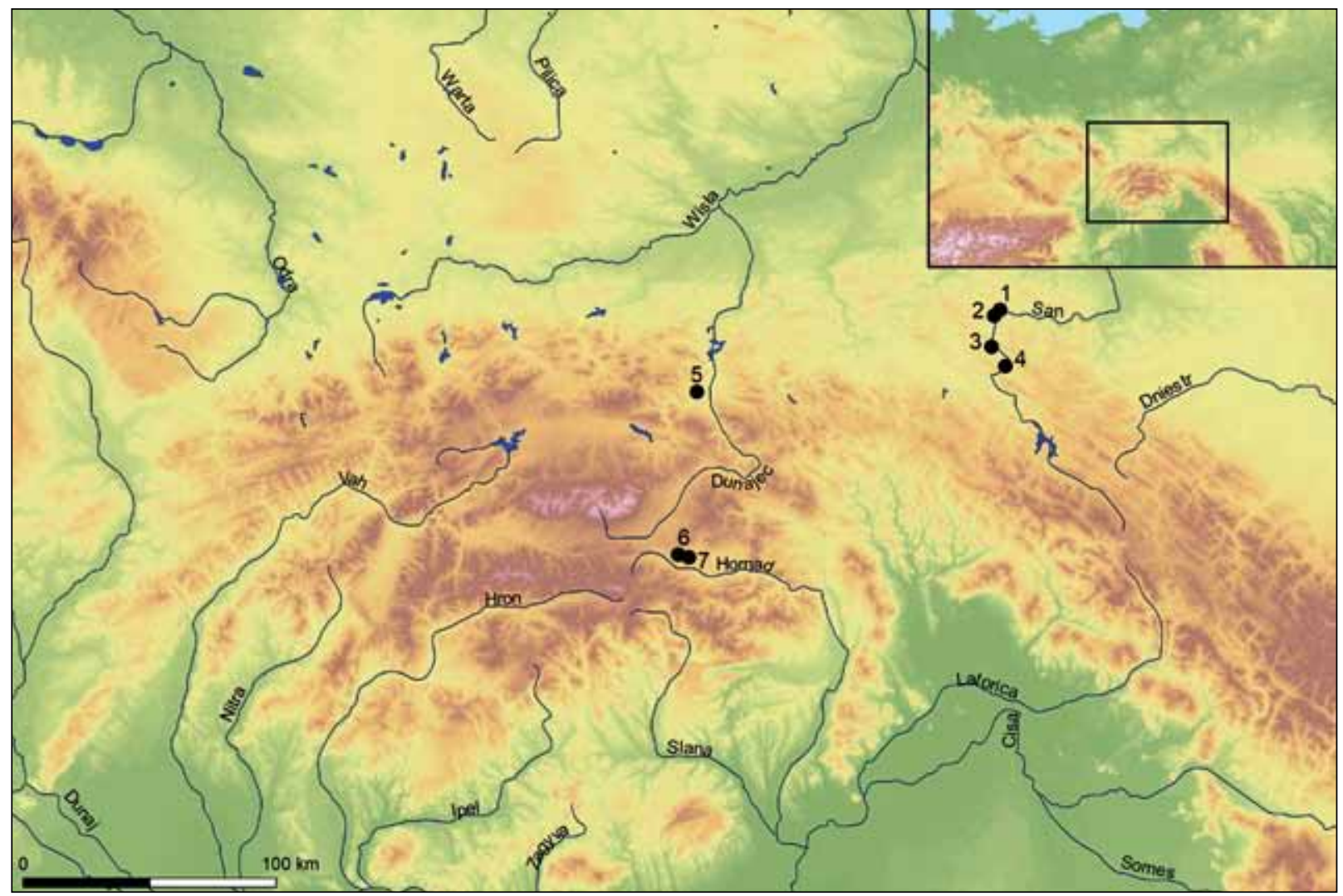

Fig. 14. Early Slavic settlement in the West Carpathians (elaborated by R. Madyda-Legutko and K. Tunia). 1 - Bachórz, Rzeszów district, site 16; 2 - Dynów, Rzeszów district, site 11;3 - Jabłonnica Ruska, Brzozów district, site 1; 4 - Hłomcza, Sanok district, site 1; 5 - Podegrodzie, Nowy Sącz district, site 9; 6-Spišský Štvrtok, Levoča district, site Pod Šibeničnou; 7 - Iliašovce, Levoča district, site Za hostincom.

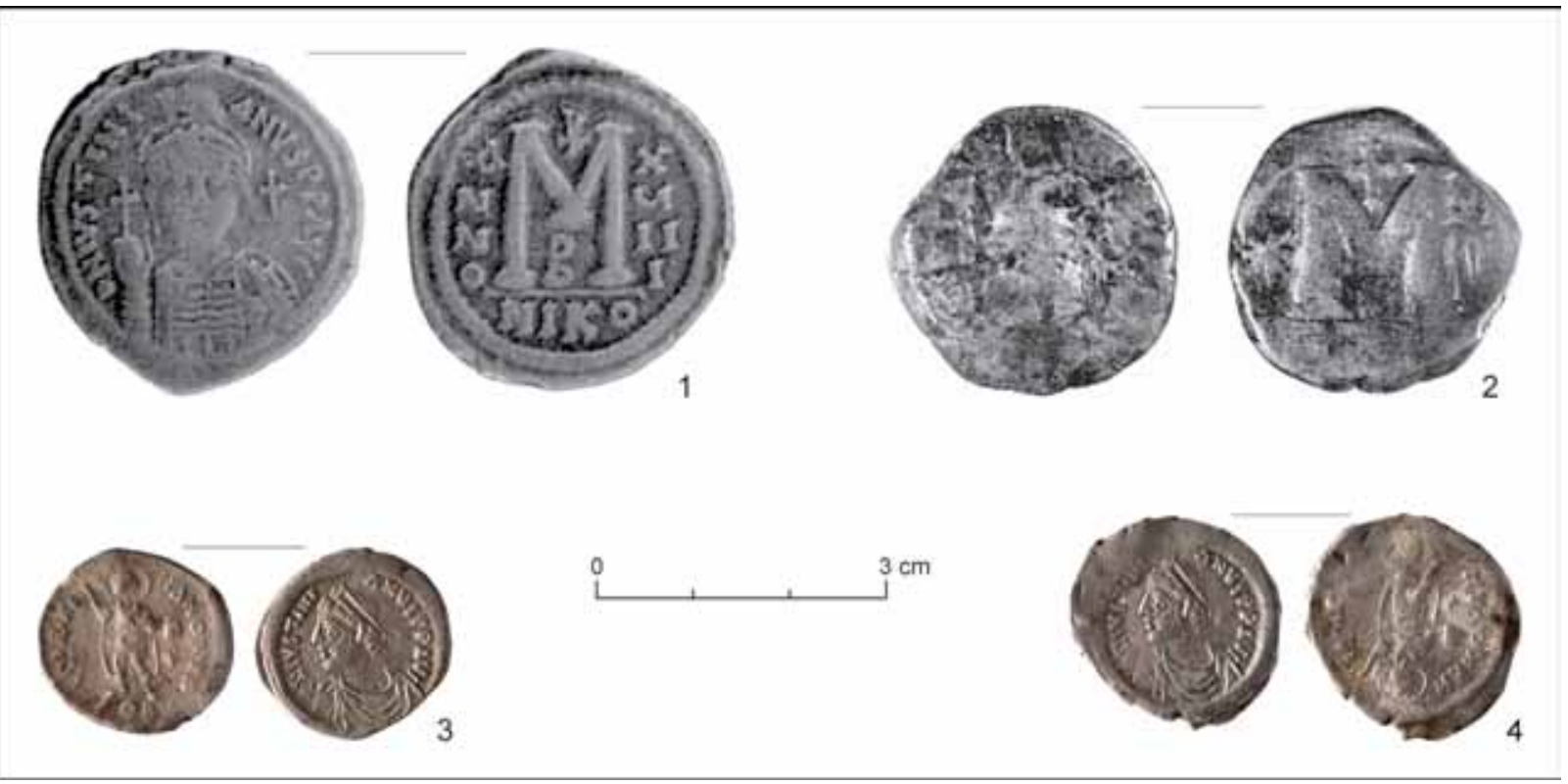

Fig. 15. Early Byzantine coins the Polish Carpathians. 1 - bronze follis from Besko, Sanok district (Salamon/Muzyczuk 2003); 2 - bronze follis from Biecz, Gorlice district (Wołoszyn 2009, fig. 6: 2); 3, 4 - silver miliarensa from the vicinity of Rabka, Nowy Targ district. Photo National Museum in Krakow, Numismatic Cabinet. 
The Early Slavic settlement in the Polish Carpathians coincides with another wave of Early Byzantine coins. These are emissions issued in the name of Justinian I in the first half of the $6^{\text {th }}$ century. To this group belong silver miliarensa from the vicinity of Rabka, Nowy Targ district (Fig. 15: 3, 43; Salamon 2004; Wołoszyn 2009, 504, 505, fig. 6: 6, 7) and bronze folies from Besko, Sanok district (Fig. 15: 1; Salamon/ Muzyczuk 2003; Wołoszyn 2009, 497), Biecz, Gorlice district (Fig. 15: 2; Wołoszyn 2009, 497, 498), and from the vicinity of Dukla, Krosno district (Wołoszyn 2009, 500) and from Żywiec, Żywiec district (Salamon/ Muzyczuk 2003, 186; Wołoszyn 2009, 506, 507, fig. 6: 14).

Due to the absence of precise chronological indicators, it is impossible at the present stage of research to precisely date the beginning of the Early Slavic settlement in Małopolska and the West Carpathians. K. Godtowski (1979, 34-36) and M. Parczewski (1988, 106-108; 1993, 88-94) formulated a hypothesis positing that the earliest Early Slavic settlement could not have appeared before the decline of the settlement structures characteristic of the Late Roman and Early Migration periods, which means not before the second half of the $5^{\text {th }}$ century. However, Early Slavic materials credibly dated to such an early period remain so far unknown, due to the mentioned absence of precise chronological indicators. Therefore, the beginning of the Early Slavic phase in Małopolska has been conventionally set around $500 \mathrm{AD}$, which is in line with the information provided by Jordanes (Labuda 1999, 34, 35; Madyda-Legutko/Poleski/Krapiec 2005, 312). In this context it is worth referring to a view expressed by $H$. Łowmianski $(1963,245,246)$, who regarded the Battle of Nedao in 454 AD (which triggered the disintegration of the multi-ethnic Hunnic empire) as a milestone in overcoming the barrier blocking Slavic expansion.

In general, the populating of the territory of present-day Poland by a Slavic element was a staged process. The older stage would encompass the historical migrations of the Sclaveni and, according to Jordanes, was confined to the upper basin of the Vistula River. According to Michał Parczewski and archaeologists of the new generation, the term "Early Slavic phase" refers to a period spanning from the mid- $5^{\text {th }}$ century until the close of the $7^{\text {th }}$ century (Szmoniewski 2016, 31). Thus, the decline of the settlement of the North Carpathian group and the beginning of that linked with early Slavs both seem to fall around the middle of the $5^{\text {th }}$ century, and there may have been a causal link between these two phenomena. It can also be assumed that the replacement of settlement structure was not always a peaceful process, as possibly indicated by the archaeologically evidenced traces of fires that brought the existence of settlements in Rytro and Lesko to an end.

Translated by Piotr Godlewski

\section{LITERATURE}

Barłowska 1984

Biborski 1995

Biborski/Ilkjær 2006

Biborski/Kaczanowski 2013

Biborski/Zagórska-Telega 2008

Biborski/Zagórska-Telega 2009
A. Barłowska: Osada z późnego okresu wędrówek ludów w Lesku, woj. Krosno. Sprawozdania i Materiały Rzeszowskiego Ośrodka Archeologicznego za lata 1976-1979, 1984, 51-101.

M. Biborski: Miecz z późnego okresu rzymskiego z miejscowości Isep, gmina Wojnicz, woj. Tarnów. Zeszyty Wojnickie. Miesięcznik Historyczny Towarzystwa Przyjaciót Ziemi Wojnickiej 12, 1995, 13, 14.

M. Biborski/J. Ilkjær: Illerup Ådal 11. Die Schwerter. Textband. Jutland Archaeological Society Publications 25. Århus 2006.

M. Biborski/P. Kaczanowski: Magic sword pendats. In: E. Istvánovits/V. Kulcsár (eds.): Proceedings of the international archaeological conference Wandering and Settled Barbarians in the Carpathian Region and Neighboring Areas $\left(1^{\text {st }}-5^{\text {th }}\right.$ cent.) New Finds, New Interpretations held in Nyíregyháza and Satu Mare October 11.-14. 2010. Jósa András Múzeum Évkönyve 55. Nyíregyháza 2013, 423-430. M. Biborski/J. Zagórska-Telega: Rajbrot, site 4, commune. Lipnica Murowana - Migration Period Cemetery. In: B. Niezabitowska-Wiśniewska et al. (eds.): The Turbulent Epoch. New materials from the Late Roman Period and the Migration Period I. Lublin 2008, 87-96.

M. Biborski/J. Zagórska-Telega: Rajbrot, Fundstelle 4. Powiat Bochnia - ein Gräberfeld der Völkerwanderungszeit. Acta Archaeologica Carpathica 42/43, 2009, 429-440.

\footnotetext{
13 National Museum in Kraków, Numismatic Cabinet. Inv. nos VIIA 3583, VIIA 3584.
} 
Bochnak 2019

Bodzek 2009

Bodzek/Fedyk/Kotowicz 2019

Bodzek/Pohorska-Kleja 2011

Bulas 2019

Bulas/Kotowicz/Okońska 2019

Bulas et al. 2019

\section{Cabalska 1971}

Čaplovič 1976

Doniec, in preparation

Dymowski 2013

Eggers 1951

Fusek 1994

Gavritukhin 2011

Giertlová-Kučerová/Soják 2005

Ginalski/Muzyczuk 2001

Godtowski 1979

Godłowski 1991

Godłowski 1995

Henning 1977

Jodłowski 1985

Kłosowicz/Leszczyński 2017
T. Bochnak: Movement or Stabilization? The Upper San River basin in the second half of the $1^{\text {st }}$ millennium BC. Acta Archaeologica Carpathica 54, 2019, 9-24.

J. Bodzek: Remarks on the Inflow of Roman Coins into Southern Poland in the Second Half of the $4^{\text {th }}$ and in the $5^{\text {th }}$ Centuries A. D. In: M. Wołoszyn (ed.): Byzantine Coins in Central Europe between the $5^{\text {th }}$ and $10^{\text {th }}$ Century. Moravia Magna. Seria Polona III. Kraków 2009, 155-204.

J. Bodzek/R. Fedyk/P. N. Kotowicz: A Late-Roman Solidus found at Prełuki (the Upper San River Basin). Acta Archaeologica Carpathica 54, 2009, 269-284.

J. Bodzek/E. Pohorska-Kleja: Znalezisko solida Walentyniana III w Prusieku, gm. Sanok, woj. podkarpackie. Notae Numismaticae/Zapiski Numizmatyczne 6, 2011, 153-162.

J. Bulas: Late Roman Period and Early Migration Period in the Upper San River basin. Acta Archaeologica Carpathica 54, 2019, 57-76.

J. Bulas/P. N. Kotowicz/M. Okońska: A new Roman Period burial ground of the Przeworsk culture from Pakoszówka (the Upper San River basin). Acta Archaeologica Carpathica 54, 2019, 91-106.

J. Bulas/M. Mazurek/M. Okońska/W. Poradyło: Wielokulturowe stanowisko 59-60 w Sanoku w świetle badań wykopaliskowych z lat 2017-2018. Raport 14, 2019, 55-81.

M. Cabalska: Użytkowanie źródeł słonej wody na Sądecczyźnie w najdawniejszych czasach. Kwartalnik Historii Kultury Materialnej 19, 1971, 431-436.

P. Čaplovič: Sídlisko z doby rímskej a slovanskej na Ostrej Skale nad Vyšným Kubínom. AVANS 1957, 1976, 78-82, 269.

I. Doniec: Osada z późnego okresu rzymskiego i wczesnej fazy okresu wędrówek ludów w Skawcach, pow. wadowicki. In preparation

A. Dymowski: Roman denarii of Tiberius and Caligula discovered in the drainage basin of the Wisłoka River in southern Poland. Acta Archaeologica Carpathica 48, 2013, 273-284.

H. J. Eggers: Der römischen Import im Freien Germanien. Atlas der Urgeschichte 1 . Hamburg 1951.

G. Fusek: Slovensko vo včasnoslovanskom období. Archaeologica Slovaca Monographiae. Studia III. Nitra 1994.

I. Gavritukhin: Cut Glass Beakers within the Context of Studies in the Connections between the South of Eastern Europe and Scandinavia in the Late Period of Roman Influence and the Great Migrations Periods. In: I. Khrapunov/F.-A. Stylegar (eds.): Inter Ambo Maria. Contacts between Scandinavia and the Crimea in the Roman Period. Kristiansand-Simferopol 2011, 39-69.

M. Giertlová-Kučerová/M. Soják: Novšie nálezy severokarpatskej skupiny v povodí rieky Poprad. Študijné zvesti AÚ SAV 38, 2005, 113-136.

J. Ginalski/A. Muzyczuk: State of research on Prehistoric and Early Medieval settlement on the northern approach of the Dukla Pass. In: J. Machnik (ed.): Archaeology and Natural Background of the Lower Beskid Mountains, Carpathians, part I. Prace Komisji Prehistorii Karpat PAU II. Kraków 2001, 191-203.

K. Godłowski: Z badań nad zagadnieniem rozprzestrzenienia Słowian $w$ V-VII $w$. n.e. Kraków 1979.

K. Godłowski: Jakuszowice - a multi-period settlement in southern Poland. Antiquity 65, 1991, 662-675.

K. Godłowski: Das „Fürstengrab” des 5. Jhs. und der „Fürstensitz” in Jakuszowice in Südpolen. In: F. Vallet/M. Kazanski (eds.): La noblesse romaine et les chefs barbares du III au VII e siècle. Condé-sur-Noireau 1995, 155-179.

J. Henning: Entwicklungstendenzen der Keramikproduktion an der mittleren und unteren Donau im. 1. Jahrtausend u. Z. Zeitschrift für Archäologie 11, 1977, 181-206.

A. Jodłowski: Badania powierzchniowe w rejonie Gór Słonych koło Sanoka. Badania archeologiczne prowadzone przez Muzeum Żup Krakowskich Wieliczka $v$ latach 1984-1985, 1985, 59-69.

M. Kłosowicz/T. Leszczyński: Wyniki badań osady z okresu wpływów rzymskich w Lipnicy Dolnej stan. 8. pow. jasielski. In: J. Gancarski (ed.): Stan i potrzeby badań archeologicznych w Karpatach. Krosno 2017, 451-519. 
Koch 1999

Kotowicz/Fedyk 2008

Kučerová et al. 2012

Labuda 1999

Lamiová-Schmiedlová/Tomášová 1999

Lau 2013

Lau/Pieta 2010

Lau/Pieta 2017

Lityńska-Zając 1993

Lityńska-Zając et al. 2017

Lofajová-Danielová/Furman 2019

Luštíková 2018

Łowmiański 1963

Madyda-Legutko 1978

Madyda-Legutko 1995

Madyda-Legutko 1996

Madyda-Legutko 1998

Madyda-Legutko 2011

Madyda-Legutko et al., in preparation
A. Koch: Zum archäologischen Nachweis der Sueben auf der Iberischen Halbinseln. Überlegungen zu einer Gürtelschnalle aus der Umgebung von Baamorto/Monforte de Lemos (Prov. Lugo, Spanien). Acta Praehistorica et Archaeologica 31, 1999, 156-198.

P. N. Kotowicz/R. Fedyk: Late-Roman Spatha from Lake Solińskie in Polańczyk. In: B. Niezabitowska-Wiśniewska et al. (eds.): The Turbulent Epoch. New materials from the Late Roman Period and the Migration Period II. Lublin 2008, 113-117.

M. Kučerová/M. Soják/A. Kušnierová/P. Fecko: Prvé včasnoslovanské nálezy zo Spiša. In: F. Fetko/M. Števík (eds.): Pocta Ivanovi Chalupeckému. Levoča 2012, 19-31.

G. Labuda: Słowiańszczyzna starożytna i wczesnośredniowieczna. Antologia tekstów źródłowych. Poznan 1999.

M. Lamiová-Schmiedlová/B. Tomášová: Nálezový horizont z prelomu doby rímskej a doby stahovania národov na viacvrstvovom sídlisku v Ostrovanoch. Slovenská archeológia 47, 1999, 75-132.

N. Lau: Das Grab von Poprad-Matejovce in der Slovakei - Ein Blockhaus mit Inneneinrichtung aus der frühen Völkerwanderungszeit. Archäologische Nachrichten aus Schleswig-Holstein 19, 2013, 16-19.

N. Lau/K. Pieta: Das Grab von Poprad-Matejovce in der Slowakei. Konstruktion, Ausstattung und Wiederöffnung eines frühvölkerwanderungszeitlichen Kammergrabes. In: A. Abegg-Wigg/N. Lau (eds.): Kammergräber im Barbaricum. Zu Einflüssen und Übergangsphänomenen von der vorrömischen Eisenzeit bis in die Völkerwanderungszeit. Schriften des Archäologischen Landesmuseums Ergänzungsreihe 9. Neumünster - Hamburg 2010, 343-364.

N. Lau/K. Pieta: Die Antike Öffnung des Kammergrabes von Poprad-Matejovce. In: Na hranicich Impéria. Extra fines Imperii. Jaroslavu Tejralovi $k 80$. narozeninám. Brno 2017, 255-265.

M. Lityńska-Zając: Odciski roślinne na polepie i węgle drzewne ze stanowiska A w Rytrze, woj. Nowy Sącz. In: Madyda-Legutko/Tunia 1993, 149-158.

M. Lityńska-Zając/M. Moskal-del Hoyo/A. Mueller-Bieniek/A. Wacnik: Stan i problematyka badań archeologicznych w polskiej części Karpat. In: J. Gancarski (ed.): Stan i potrzeby badań archeologicznych w Karpatach. Krosno 2017, 719-750.

B. Lofajová-Danielová/M. Furman: Hrdoš - Nová archeologická lokalita severokarpatskej skupiny na pomedzí Oravy a Liptova. Zborník Slovenského národného múzea, Archeológia 29, Ročník 113, 2019, 269-281.

L. Luštíková: Lokality doby rímskej na východnom Slovensku. Východoslovenský pravek 11, 2018, 75-109.

H. Łowmiański: Początki Polski. Z dziejów Słowian w I tysiacleciu n. e. 2. Warszawa 1963.

R. Madyda-Legutko: The buckle with imprint ornamentation. Wiadomości Archeologiczne 43, 1978, 3-16.

R. Madyda-Legutko: Zróżnicowanie kulturowe polskiej strefy beskidzkiej w okresie lateńskim i rzymskim. Katalog stanowisk. Rozprawy Habilitacyjne 304. Kraków 1995.

R. Madyda-Legutko: Zróżnicowanie kulturowe polskiej strefy beskidzkiej w okresie lateńskim i rzymskim. Rozprawy Habilitacyjne 304. Kraków 1996.

R. Madyda-Legutko: Importy rzymskie w polskich Karpatach. In: J. Kolendo (ed.): Korpus znalezisk rzymskich z europejskiego Barbaricum. Polska. Suplement tom 1. Nowe znaleziska importów rzymskich z ziem Polski I. Warszawa 1998, 29-39.

R. Madyda-Legutko: Drehscheibenkeramik aus dem Gebiet der polnischen Karpaten. Zur regionalen Differenzierung. In: J. Bemmann/M. Hegewisch/M. Meyer/M. Schmauder (eds.): Drehscheibentöpferei im Barbaricum. Technologietranfer und Professionalisierung eines Handwerks am Rande des Römischen Imperiums. Bonner Beiträge zur Vor- und Frühgeschichtlichen Archäologie 13. Bonn 2011, 295-306.

R. Madyda-Legutko/P. Kotowicz/E. Pohorska-Kleja/J. Rodzińska-Nowak: Osada na stan. 54 w Sanoku, gm. Sanok, woj. podkarpackie. In: R. Madyda-Legutko/J. Rodzińska-Nowak (eds.): Osady z okresu rzymskiego z terenu dorzecza górnego Sanu. In preparation. 
Madyda-Legutko/Pohorska-Kleja/Rodzińska-Nowak, in preparation

R. Madyda-Legutko/E. Pohorska-Kleja/J. Rodzińska-Nowak: Osada na stan. 1 w Pakoszówce, gm. Sanok, woj. podkarpackie. In: R. Madyda-Legutko/ J. Rodzińska-Nowak (eds.): Osady z okresu rzymskiego z terenu dorzecza górnego Sanu. In preparation.

Madyda-Legutko/Poleski/Krapiec 2005 R. Madyda-Legutko/J. Poleski/M. Krąpiec: Studia nad geografią osadnictwa w górnym dorzeczu Wisły u schyłku starożytności i na początku średniowiecza. In: P. Kaczanowski/M. Parczewski (eds.): Archeologia o początkach Słowian. Kraków 2005, 307-352.

Madyda-Legutko/Rodzińska-Nowak 2010 R. Madyda-Legutko/J. Rodzińska-Nowak: Die kulturelle Situation im oberen Sangebiet in der römischen Kaiserzeit im Lichte der neuesten Forschungen. Recherches Archéologiques 2, 2010, 65-77.

Madyda-Legutko/Rodzińska-Nowak 2019 R. Madyda-Legutko/J. Rodzińska-Nowak: New Data of the Migration of Vandalic Group in the Direction of Dacia. In: A. Cieśliński/B. Kontny (eds.): Interacting Barbarians. Contacts, Exchange and Migrations in the First Millennium $A D$. Neue Studien zur Sachsenforschung 9. Warszawa - Braunschweig Schleswig 2019, 247-257.

Madyda-Legutko/Tunia 1978

R. Madyda-Legutko/K. Tunia: Wyniki badań stanowisk okresu rzymskiego w Moszczenicy Wyżnej, woj. Nowy Sącz. Acta Archaeologica Carpathica 18, 1978, 113-149.

Madyda-Legutko/Tunia 1980

R. Madyda-Legutko/K.Tunia: Wyniki badań stanowiska z okresu rzymskiego w Piwnicznej, woj. Nowy Sącz. Acta Archaeologica Carpathica 20, 1980, 143-152.

Madyda-Legutko/Tunia 1991

R. Madyda-Legutko/K.Tunia: Die ersten Spuren der frühslawischen Besiedlung in den West-Beskiden. In: M. Parczewski (ed.): Archaeoslavica 1. Kraków 1991, 83-93.

Madyda-Legutko/Tunia 1992

Madyda-Legutko/Tunia 1993

R. Madyda-Legutko/K. Tunia: Wczesnosłowiańskie osadnictwo w Podegrodziu, woj. Nowy Sącz. Acta Archaeologica Carpathica 31, 1992, 123-146.

R. Madyda-Legutko/K. Tunia: Ryto. Karpacka osada z okresu wędrówek ludów. Zeszyty Naukowe Uniwersytetu Jagiellońskiego 1118. Prace Archeologiczne 57. Kraków 1993.

Madyda-Legutko/Tunia 2008

R. Madyda-Legutko/K. Tunia: Late Roman and Early Migration Period in Polish Beskid Mts. Carpathians. Settlement Aspect. In: B. NiezabitowskaWiśniewska et al. (eds.): The Turbulent Epoch. New materials from the Late Roman Period and the Migration Period I. Lublin 2008, 227-248.

Madyda-Legutko/Tunia 2015

Mączyńska 1999

Morawiecki 1977

Muzyczuk/Pohorska-Kleja 1994

Parczewski 1988

Parczewski 1993

Parczewski 1996

R. Madyda-Legutko/K. Tunia: Osady obronne (?) ludności kultury puchowskiej nad Dunajcem. In: J. Gancarski (ed.): Pradziejowe osady obronne w Karpatach. Krosno 2015, 347-380.

M. Mączyńska: Schyłkowa faza kultury przeworskiej. In: A. Kokowski (ed.): Kultura Przeworska IV. Lublin 1999, 25-53.

L. Morawiecki: Monety rzymskie z okolic Nowego Sącza, Acta Archaeologica Carpathica 17, 1977, 171-180.

A. Muzyczuk/E. Pohorska-Kleja: Wyniki badań wykopaliskowych w Hłomczy, gm. Sanok, woj. krośnieńskie w latach 1981-1985 I. Materiały i Sprawozdania Rzeszowskiego Ośrodka Archeologicznego za rok 1993, 1994, 55-154.

M. Parczewski: Najstarsza faza kultury wczesnosłowiańskiej w Polsce. Kraków 1988. M. Parczewski: Die Anfünge der frühslawischen Kultur in Polen. Veröffentlichungen der österreichischen Gesselschaft für Ur- und Frühgeschichte 17. Wien 1993.

M. Parczewski: Rezultaty badań wykopaliskowych w Bachórzu w latach 1993-1995. Materiaty i Sprawozdania Rzeszowskiego Ośrodka Archeologicznego 17, 1996, 263-282.

Parczewski 2003

M. Parczewski: Wczesnośredniowieczne odkrycia w Bachórzu, pow. Rzeszów. In: Z. Woźniak/J. Gancarski (eds.): Polonia Minor Medii Aevi. Studia ofiarowane Panu Profesorowi Andrzejowi Żakowi w osiemdziesiata rocznice urodzin. Kraków - Krosno 2003, 191-209.

Parczewski 2011 M. Parczewski: Osady wczesnosłowiańskie (V/VI-VII w.) na trasie autostrady A4 w południowo-wschodniej Polsce. In: S. Czopek (ed.): Autostrada w przeszłość. Katalog wystawy. Rzeszów 2011, 97-106.

Parczewski/Pelisiak/Szczepanek 2012 M. Parczewski/A. Pelisiak/K. Szczepanek: Najdawniejsza przeszłość polskich Bieszczadów. Materiaty i Sprawozdania Rzeszowskiego Ośrodka Archeologicznego 33, 2012, 9-42. 
Pawlikowski 1993

Pęcherek 2018

Pieta 1987

Pieta 1991

Pieta 1992

Pieta 1994

Pieta 2002

Pieta 2003

Pieta 2008

Pieta 2009

Pohorska 1978

Prohászka 2006

Przychodni/Tunia 2019

Ralska-Jasiewiczowa 1980

Rau 1972

Salamon 2004

Salamon/Muzyczuk 2003

Skowronek/Ślawski 1966

Szałapata 1966

Szmoniewski 2016

Tejral 2011

Tunia 1986
M. Pawlikowski: Wyniki badań mineralogicznych amfory ze stanowiska A w Rytrze, woj. Nowy Sącz. In: Madyda-Legutko/Tunia 1993, 159-161.

D. Pęcherek: Osada z późnego okresu wpływów rzymskich i wczesnej fazy okresu wędrówek ludów w Ujeździe st. 1, gm. Brzyska, woj. podkarpackie. Maszynopis prac magisterskiej (Instytut Archeologii Uniwersytetu Jagiellońskiego). Kraków 2018. Unpublished.

K. Pieta: Die Slowakei im 5. Jahrundert. In: G. Bott (ed.): Germanen, Hunen und Awaren. Schätze der Völkerwanderungszeit. Nürnberg 1987, 385-417.

K. Pieta: The North Carpathians at the beginning of the Migration Period. Antiquity 65, 1991, 376-387.

K. Pieta: Nálezy zo začiatku doby stłahovania národov v Liptovskom Jáne. AVANS 1990, 1992, 86-87.

K. Pieta: Mittel- und Nordslowakei zur Zeit der Markomannenkriege. In: H. Friesinger/J. Tejral/A. Stuppner (eds.): Markomannenkriege. Ursachen und Wirkungen. Spisy AÚ AV ČR Brno 1. Brno 1994, 254, 256.

K. Pieta: Osídlenie Slovenska v dobe stahovania národov. In: A. Ruttkay/ M. Ruttkay/P. Šalkovský (eds.): Slovensko vo včasnom stredoveku. Nitra 2002, 11-22.

K. Pieta: Spiš vo včasnej dobe dejinnej. In: R. Gładkiewicz/M. Homza (eds.): Terra Scepusiensis. Stan badań nad dziejami Spiszu. Levoča - Wrocław 2003, 149-159.

K. Pieta: Hohensiedlungen der Völkerwanderungszeit im nördlichen Karpatenbecken. In: H. Steuer/V. Bierbrauer (eds.): Ergänzungsbände zum Reallexikon der Germanischen Altertumskunde 58. Hohensiedlungen zwischen Antike und Mittelalter von der Ardennen bis zur Adria. Berlin - New York 2008, 457-480.

K. Pieta: Das germanische Fürstengrab aus Poprad-Matejovce. In: U. von Freeden/H. Friesinger/E. Wamers (eds.): Glaube, Kult und Herrschaft. Phänomene des Religiösen im 1. Jahrtausend n. Chr. in Mittel- und Nordeuropa. Akten des 59. International Sachsensymposions und der Grundprobleme der frühgeschichtlichen Entwicklung im Mitteldonauraum. Kolloquien zur Vor- und Frühgeschichte 12. Bonn 2009, 107-122.

E. Pohorska: Późnorzymska osada w Ujeździe, woj. Krosno. Badania 1975 r. Acta Archaeologica Carpathica 18, 1978, 247-260.

P. Prohászka: Das vandalische Königsgrab von Osztrópataka. Monumenta Germanorum Archaeologica Hungariae 3. Budapest 2006.

A. Przychodni/K. Tunia: A unique fragment of a Terra Sigillata vessel from the Polish Carpathians. Acta Archaeologica Carpathica 54, 2019, 259-268.

M. Ralska-Jasiewiczowa: Late-Glacial and Holocene Vegetation of the Bieszczady Mts. (Polish Eastern Carpathians). Warszawa - Kraków 1980.

G. Rau: Körpergräber mit Glasbeigaben des 4. nachchristliche Jahrhunderts im Oder-Weichsel-Raum. Acta Praehistorica et Archaeologica 3, 1972, 109-214.

M. Salamon: Znalezisko miliarensów Justyniana I z doliny Raby. Próba interpretacji numizmatycznej. In: W. Kaczanowicz (ed.): Studia z dziejów antyku. Pamięci Profesora Andrzeja Kunisza. Prace Naukowe Uniwersytetu Śląskiego 2166. Katowice 2004, 251-271.

M. Salamon/A. Muzyczuk: Znalezisko brązowej monety bizantyjskiej z Beska, pow. Sanok. In: Z. Woźniak/J. Gancarski (eds.): Polonia Minor Medii Aevi. Studia ofiarowane Panu Profesorowi Andrzejowi Żakowi w osiemdziesiata rocznice urodzin. Kraków - Krosno 2003, 181-190.

S. Skowronek/T. Ślawski: Nieznane monety starożytne z okolic Biecza (Podkarpacie polskie). Acta Archaeologica Carpathica 8, 1966, 203-205.

A. Szałapata: Badania archeologiczne w Świerchowej, pow. Jasło. Sprawozdania i Materiały Rzeszowskiego Ośrodka Archeologicznego za rok 1965, 1966, 35-44. B. Sz. Szmoniewski: Early-Slavic culture. In: P. Urbańczyk (ed.): The Past Societes. Polish Lands from the First Evidence of Human Presence to the Early Middle Ages. 500 AD - 1000 AD. Warszawa 2016, 21-73.

J. Tejral: Einheimische und Fremde. Das norddanubische Gebiet zur Zeit der Völkerwanderung. Spisy AÚ AV ČR v Brně 33. Brno 2011.

K. Tunia: Z problematyki środowiskowych uwarunkowań gospodarki pasterskiej na terenie górskiej strefy polskich Karpat Zachodnich w czasach prahistorycznych. Acta Archaeologica Carpathica 25, 1986, 119-230. 
Tunia 1989

Tunia 2001

Tunia 2004

Tunia 2008

Vaday 1994

Valde-Nowak 2014

Wilk 2005

Wołoszyn 2009
K. Tunia: Umweltbedingtheiten der Agrar- und Viehzucht - Wirtschaft auf den gebirgigen Gebieten in der Urgeschichte. Casus der westkarpatischen spatkaiserzeitlichen Besiedlung. Acta Archaeologica Carpathica 28, 1989, 119-144.

K. Tunia: Prehistoric Settlement of the Southern Slopes of the Lower Beskid Mountains. In: J. Machnik (ed.): Archaeology and Natural Background of the Lower Beskid Mountains, Carpathians, part I. Prace Komisji Prehistorii Karpat PAU II. Kraków 2001, 111-125.

K. Tunia: Środowiskowe uwarunkowania gospodarki rolniczo-hodowlanej na terenach górskich $\mathrm{w}$ czasach prahistorycznych. Casus zachodniokarpackiego osadnictwa późnorzymskiego. In: J. Gancarski (ed.): Okres lateński i rzymski w Karpatach polskich. Krosno 2004, 329-356.

K. Tunia: Słowacko-Polskie archeologiczne badania powierzchniowe w górnym dorzeczu Topli, Słowacja. In: J. Machnik (ed.): Archeologia i środowisko naturalne Beskidu Niskiego w Karpatach II. Kurimska Brazdá. Prace Komisji Prehistorii Karpat PAU IV. Kraków 2008, 41-138.

A. Vaday: Late Sarmatian Graves and their connections within the Great Hungarian Plain. Slovenská archeológia 42, 1994, 105-124.

P. Valde-Nowak: Ślady osadnictwa z okresu rzymskiego w dolinie Skawy w Zachodnich Beskidach. In: R. Madyda-Legutko/J. Rodzińska-Nowak (eds.): Honoratissimum assensus genus est armis laudare. Studia dedykowane Profesorowi Piotrowi Kaczanowskiemu z okazji siedemdziesiatej rocznicy urodzin. Kraków 2014, 483-489.

M. Wilk: Późnorzymskie naczynia zasobowe (w typie Krausengefäße) na obszarze południowo-wschodniej Polski. Materiały i Sprawozdania Rzeszowskiego Ośrodka Archeologicznego 26, 2005, 305-372.

M. Wołoszyn: Byzantinische Münzen aus dem 6.-7. Jh. in Polen. In: M. Wołoszyn (ed.): Byzantine Coins in Central Europe between the $5^{\text {th }}$ and $10^{\text {th }}$ Century. Moravia Magna, Seria Polona III. Kraków 2009, 473-530.

\section{Koniec staroveku a začiatok novej éry v pol'ských Karpatoch}

\author{
Renata Madyda-Legutko-Krzysztof Tunia
}

Jednou z najzložitejších otázok praveku je vývoj archeologických kultúr. Fázy ich viac či menej stabilného trvania sú spravidla dobre definované, zatial čo otázky vzniku a rozkladu sú ovela komplikovanejšie a často kontroverzné. Nie je to inak ani v prípade konca staroveku a začiatku stredoveku v Západných Karpatoch, ktorým sme už venovali vel'kú pozornost a sú predmetom uvedených úvah.

V dôsledku terénneho výskumu, uskutočneného v posledných rokoch, už beskydská čast' pol’ských Karpát nie je terra incognita na archeologickej mape stredoeurópskeho Barbarika v neskorej dobe rímskej a v ranej fáze obdobia stahovania národov. Naopak, tento región bol oblastou, ktorú v tomto období vel'mi intenzívne využívali komunity, ktoré tu sídlili.

Aktuálny obraz osídlenia z konca doby rímskej a ranej fázy obdobia stahovania národov v predmetnej oblasti, v Pol'sku aj na Slovensku, je samozrejme odrazom súčasného stavu bádania. Jeho vývoj môže v budúcnosti viest’ k úpravám dnešnej vízie. Pomerne dobre rozpoznané osídlenie v oblasti medzihorských kotlín, Oravy, Spiša, Liptova, okolia Nového Sączu a prilahlých pohorí, definoval K. Pieta ako severokarpatskú skupinu (nordkarpatische Gruppe).

V súčasnosti z oblasti pol'ských Karpát poznáme hlavne sídliská. Zo sledovaného chronologického úseku bolo preskúmané jedno malé pohrebisko v Rajbrote, okr. Bochnia, v Beskydách Wyspowych. Je to viacvrstvové žiarové pohrebisko, datované do ranej fázy obdobia stahovania národov. V tejto súvislosti stojí za zmienku aj elitný „kniežací“ hrob z relatívne ned’alekej oblasti horného Popradu, z lokality Poprad-Matejovce, okr. Poprad, datovaný na koniec 4. storočia. Patrí k jediným dokladom pohrebísk zo sledovaného chronologického úseku. 
Analýza sídelnej siete v neskorej dobe rímskej a v ranej fáze obdobia stahovania národov v pol’ských Karpatoch ukazuje, že obyvatelia mali hlboké znalosti prírodného prostredia a dokázali ho optimálne využívat. Sídliská z predmetného obdobia sú charakteristické špecifickým umiestnením. Vel'mi často sú lokalizované vo vyšších častiach terénu, v pásmach rozvodí a na plošinách svahov. Zvyčajne ide o malé, jednodvorcové osady nachádzajúce sa na čistinách roztrúsených $\mathrm{v}$ zmiešaných listnatých lesoch (Tilio-Carpinetum) a v dubovo-borovicových lesoch (Pino-Quercetum), ktoré tvoria základnú jednotku sídelnej siete. Tieto sídla sprevádzali rozlahlé sídliská so zložitou zástavbou, situované v širokých údoliach riek, na bezpečných, nivných lokalitách na okrajoch terás. Najvyššie položené lokality v pol’ských Karpatoch dosahujú až 600 m n. m. a v slovenských Karpatoch dosahujú výšku cez $800 \mathrm{~m}$. Ekonomika týchto spoločenstiev bola založená na polnohospodárstve, pestovaní a spracovaní obilnín a chove.

Dôležitou otázkou, ktorá si vyžaduje d’alšie štúdium, je otázka etnickej štruktúry komunity, ktorá v tom čase obývala sledovanú čast’ Karpát. V súčasnej fáze výskumu sa upozorňuje na vysoký podiel prvkov hmotnej kultúry pochádzajúcich z rôznych častí strednej Európy, najmä z Karpatskej kotliny a východnej Európy. Táto zložka výrazne prevyšuje stav charakteristický pre vtedajšie „klasické“ skupiny przeworskej kultúry.

Osídlenie severokarpatskej skupiny v pol'ských aj slovenských Karpatoch koreluje s koncom doby rímskej a s ranou fázou obdobia st’ahovania národov, teda so stupňom C3-D1 a D2 podla J. Tejrala. V novšom pohlade na chronológiu doby stahohovania národov ho môžeme datovat’ medzi roky 380-390/400-440/450. Je potrebné zdôraznit', že obdobie fungovania osád severokarpatskej skupiny sa zhodovalo s vel'kými etnickými posunmi v strednej Európe, rozpadom starých kultúrnych, sídelných štruktúr a nadvládou hunských kmeňov v Karpatskej kotline. Predpokladá sa, že osídlenie severokarpatskej skupiny zaniklo pred polovicou 5. storočia, rovnako ako dalšie kultúrne štruktúry v stredoeurópskom Barbariku. Koniec fungovania osád bol pravdepodobne náhly, čo v archeologickom materiáli dokumentovali stopy po požiaroch, zretelne viditel’né napríklad na osadách v Rytre, okr. Nowy Sącz a Lesku, okr. Lesko. Palynologické údaje tiež potvrdzujú kolaps osídlenia v diskutovanom období. Je však potrebné zdôraznit', že nálezy neskororímskych mincí z pol’skej časti Karpát, najmä z oblasti horného Sanu, naznačujú, že región bol explorovaný aj po polovici 5. storočia.

Nový kultúrny cyklus sa začal v Západných Karpatoch, spolu s procesom prenikania včasnoslovanského osídlenia súvisiaceho s tzv. kultúrou pražského typu. Na základe súčasných a neustále pribúdajúcich poznatkov o vtedajšom osídlení sa nad Sanom dá pozorovat' koncentrácia včasnoslovanských sídlisk, a to nielen popri jeho strednom toku. Ďalej na západ boli včasnoslovanské náleziská v Sądeckej kotline popri rieke Dunajec. Včasnoslovanské osídlenie je doložené aj na Spiši a severozápadnom Slovensku.

V súčasnej fáze výskumu je t’ažké určit presný začiatok včasnoslovanskej fázy osídlenia v Malopol’sku a v Západných Karpatoch, a to z dôvodu nedostatku chronologicky citlivých nálezov. Predpokladá sa, že proces napĺñania pol’ských krajín slovanským elementom prebiehal v niekol'kých etapách, v staršej sa sústredil na hornom povodí Visly. Výrazom „,včasnoslovanská fáza“ sa môže označit’ obdobie od polovice 5. storočia do konca 7. storočia. Zdá sa teda, že koniec osídlenia severokarpatskej skupiny a začiatok včasnoslovanského osídlenia sa datuje zhruba do polovice 5. storočia. Možno medzi týmto prielomom osídlenia existuje vztah príčin a následkov. Dá sa tiež predpokladat', že zánik starých sídliskových štruktúr a vznik nových neprebiehal vždy pokojným spôsobom. Svedčia o tom vyššie spomínané požiare, ktoré ukončili život sídiel severokarpatskej skupiny.

Obr. 1. Osídlenie neskorej doby rímskej a ranej fázy obdobia st’ahovania národov v pol’ských Beskydách. Legenda: a - hranica oblasti Beskýd. Spracovala R. Madyda-Legutko.

Obr. 2. Osídlenie neskorej doby rímskej a ranej fázy obdobia stahovania národov vo východnej časti v Jasielsko-Krośnieńskiej kotline spolu s Nízkymi Beskydami a horným povodím Sanu (podla Madyda-Legutko 1995, mapa 4).

Obr. 3. Oblast’ Sądeckej kotliny. Nálezy z 3. storočia. 1 - Łukowica, okr. Limanowa, lokalita 5 (foto B. Urbański); 2 - Gostwica, okr. Nowy Sącz (foto B. Urbański); 3 - Stronie, okr. Limanowa, lokalita 47 (foto K. Mazur).

Obr. 4. Rajbrot, okr. Bochnia, lokalita 1. Výber nálezov z pohrebiska z obdobia stahovania národov. Spracovala U. Bąk. Mierka: a-1-4; b-5.

Obr. 5. Poloha lokalít z neskorej doby rímskej a ranej fázy obdobia stahovania národov. 1 - Piwniczna, okr. Nowy Sącz, lokalita A; 2 - Uherce Mineralne, okr. Lesko, lokalita 17; 3 - Nowy Sącz-Biegonice, okr. Nowy Sącz, lokalita 20; 4 - Lesko, okr. Lesko, lokalita 4 (podla Madyda-Legutko/Tunia 2008).

Obr. 6. Rytro, okr. Nowy Sącz, lokalita A. Zásobnice typu Krausengefäß. Foto K. Tunia.

Obr. 7. Keramika zo Sądeckých Beskydov a Sądeckej kotliny. 1, 2, 4 - Rytro, okr. Nowy Sącz, lokalita A (podla Madyda-Legutko/Tunia 1993, tab. XVI: c; XXXVII: a; foto M. Grygiel); 3 - Moszczenica Wyżna, okr. Nowy Sącz, lokalita A (podla Madyda-Legutko/Tunia 1998, obr. 9: g; foto M. Grygiel); 5 - Podegrodzie, okr. Nowy Sącz (foto A. Susuł).

Obr. 8. Keramika z pol'skej (1-3, 7-9) a slovenskej (4-6) karpatskej oblasti. 1, 2 - Rytro, okr. Nowy Sącz, lokalita A (podla Madyda-Legutko/Tunia 1993, tab. XIX: a; XX: a; foto M. Grygiel); 3 - Moszczenica Wyżna, okr. Nowy Sącz, lokalita A (podla Madyda-Legutko/Tunia 1978, obr. 9: d-e); 4 - Vrbov, okr. Kežmarok (podla Pieta 1987, obr. 3: 12, 13); 5 - Liptovský Ján, okr. Liptovský Mikuláš (podla Pieta 1991, obr. 5: 2); 6 - Ostrovany, okr. Sabinov (podla Lamiová-Schmiedlová/Tomášová 1999, tab. XII: 8); 7-9 - Rytro, okr. Nowy Sącz, lokalita A (podla Madyda-Legutko/ Tunia 1993, tab. XI: a; XII:b; XXXVI: e; foto M. Grygiel). 
Obr. 9. Keramika z pol'ských Karpát. 1, 4, 5 - Skawce, okr. Wadowice, lokalita 4 (podla Doniec, v príprave); 2, 3 Ujazd, okr. Jasło, lokalita 1 (podla Pęcherek 2018). Mierka: a -1-3; b-4, 5 .

Obr. 10. Sanok, okr. Sanok, lokalita 59, 60. Výber keramiky zo sídliska (podla Bulas et al. 2019, obr. 15: 2, 8; 16: 1; 17: 4, 6).

Obr. 11. Kovové a sklenené predmety z pol’ských Karpát. 1 - Solina, okr. Lesko (podla Kotowicz/Fedyk 2008, obr. 2); 2 - Ostrów, okr. Tarnów (podla Biborski 1995, obr. 2); 3, 4 - Lesko, okr. Lesko, lokalita 4 (podla Madyda-Legutko 1998, obr. 2: 7, 8); 5 - Sanoczek, okr. Sanok (podla Bodzek/Pohorska-Kleja 2011, tab. I: 2); 6 - Strzegocice, okr. Dębica (podla Madyda-Legutko 1978, obr. 1; foto K. Pollesch); 7 - Międzybrodzie, okr. Sanok (podla Bodzek/Fedyk/Kotowicz 2019, 276; foto archív Muzea Historycznego v Sanoku); 8 - Sanok, okr. Sanok, lokalita 59-60 (podla Bulas et al. 2019, obr. 18: 3); 9 -Pakoszówka, okr. Sanok, lokalita 33 (podla Bulas 2019, obr. 3: 3). Mierka: a -1, 2; b-3-9.

Obr. 12. Zlaté solidusy z pol’ských Karpát. 1 - Prełuki, okr. Sanok (podla Bodzek/Fedyk/Kotowicz 2019, obr. 1: 2); 2 - Prusiek, okr. Sanok, sadrový odtlačok (podl’a Bodzek/Pohorska-Kleja 2011, tab. I: 1); 3 - Sławęcin, okr. Jasło (podla Bodzek 2009, obr. 4: 7).

Obr. 13. Včasnoslovanské nálezy z Podegrodzia, okr. Nowy Sącz, lokalita 9. 1 - lokalizácia náleziska; 2 - popolnica z hrobu 1; 3-5 - keramika z objektu 26 (podla Madyda-Legutko/Tunia 1992, obr. 1; 4; 6; 7: b).

Obr. 14. Včasnoslovanské osídlenie v Západných Karpatoch (spracovali R. Madyda-Legutko, K. Tunia). 1 - Bachórz, okr. Rzeszów, lokalita 16; 2 - Dynów, okr. Rzeszów, lokalita 11; 3 - Jabłonnica Ruska, okr. Brzozów, lokalita 1; 4 - Hłomcza, okr. Sanok, lokalita 1; 5 - Podegrodzie, okr. Nowy Sącz, lokalita 9; 6 - Spišský Štvrtok, okr. Levoča, poloha Pod Šibeničnou; 7 - Iliašovce, okr. Levoča, poloha Za hostincom.

Obr. 15. Včasnobyzantské mince z pol'ských Karpát. 1- bronzový follis z Beska, okr. Sanok (podla Salamon/Muzyczuk 2003); 2 - bronzový follis z Biecza, okr. Gorlice (podla Wołoszyn 2009, obr. 6: 2); 3, 4 - strieborné miliarensy z okolia Rabky, okr. Nowy Targ (foto Muzeum Narodowe Kraków, Gabinet Numizmatyczny).

Preložil Mgr. Zbigniew Robak, PhD.

Prof. Renata Madyda-Legutko

Uniwersytet Jagielloński w Krakowie

Instytut Archeologii

ul. Gołębia 11

PL - 31-007 Kraków

rmlegutko@o2.pl
PhD Krzysztof Tunia

Polska Akademia Nauk

Instytut Archeologii i Etnologii

ul. Sławkowska 17

PL - 31-016 Kraków

ktunia@gmail.com 
